\title{
عتبات السرد من العلامات إلى التأويل رواية "الميراث لـ "سحر خليفة" نمونجا
}

\author{
نجلاء علي أحمد مشعل \\ مدرس الدراسات الأدبية بكلية الآداب

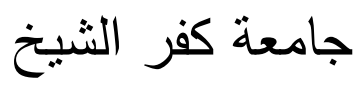


$-117-$ 


\section{عتبات السرد من العلامات إلى التأويل}

\section{رواية "الميراث لـ "سحر خليفة "نموذجا}

أصبحت عتبات النص تحظى باهتمام كبير وملحوظ في الدراسـات الأدبيـة، حتى صسارت تمتلك نظريتها الخاصـة فيما عرف بـ "علم العنونـة" باهي" الساعي نحو بحث الدور الذي يؤديه النص الموازي، وخاصـة العنوان على لإنى مستوى الإبداع والتلقي. فالنص والعتبات لحُمـة العمل وسداه، ظل الأول طويلاً مادة البحث ومجال اهتمام النقاد، فلم يولِ المبدعون العرب اهتمامهم للعتبات، وواكبهح النقاد في صنيعهم، ثم ما لبث أن تغيّر الأمر إبداعا ونقدا، فأصبح للعتبات

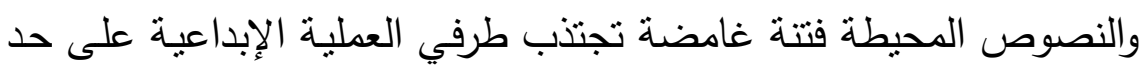
سواء، ولقد لفت القرآن الكربم - النص الإبلاغي الجمالي الأعلى - الانتباه إلى أهمية العتبات في أسماء السور وفواتحها المعزة في الحروف المقطعة الِباء التي لما تكثف عن أسرارها بعد.

والعتبات أو النصوص المحيطة (pratexte) أحد أنماط المتعاليات النصية التي أشار إليها (جيرارجينت) في (طروس) أو (أطراس) ('), ثم أفرد لها كتاب (عتبات)، وعني بمصطلح العتبات " ذلك النص الموازي لنصـه النه

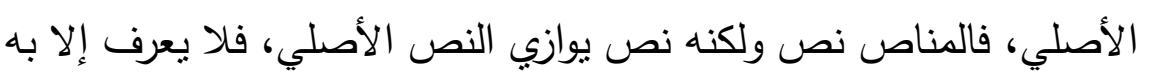

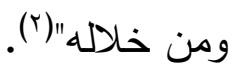

( (1) جيرار جينت طروس من كتاب آفاق التتاصية، ت محمد خير البقاعي، الهيئة المصرية

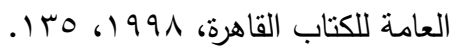
(ץ) عبد الحقق بلعابد، عتبـات جيرار جينت مـن النص إلـى المنـاص، منشـورات لاختلاف

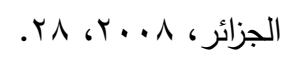


وقد اختلفت مصطلح (pratexte) ما بين عتبات ونصوص موازية أو محاذية أو مُناصن، أو النصوص المرافقة أو الملحقات، فالنص الموازي

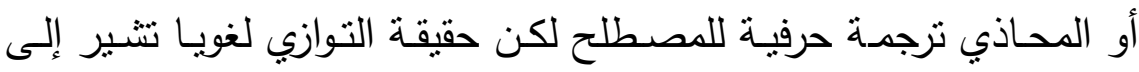

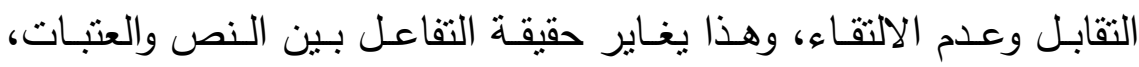

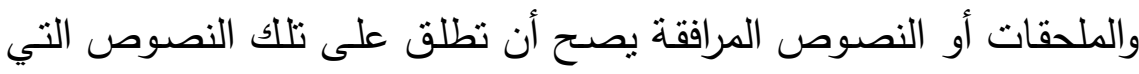

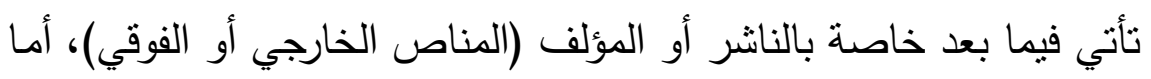

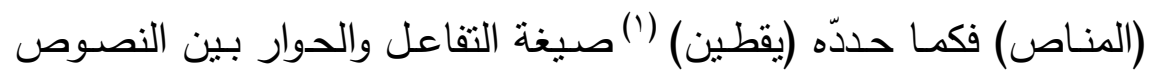

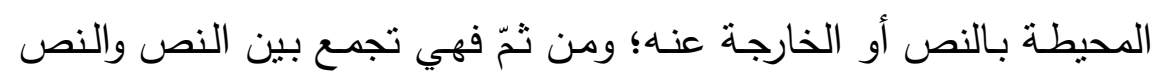

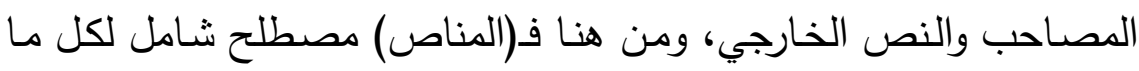

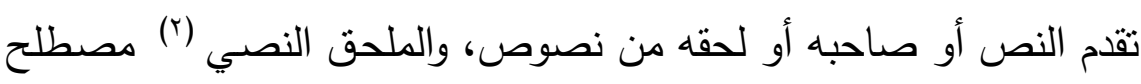
(محمد خير البقاعي) لـ(pratexte) يتضـمن في جذره اللغوي الإدراك

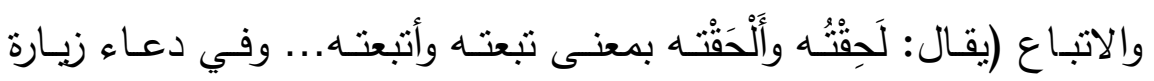

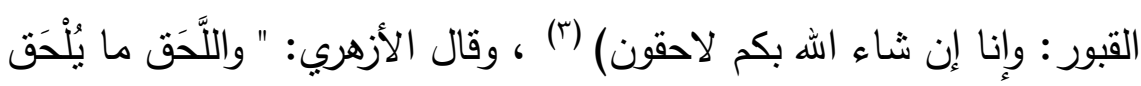

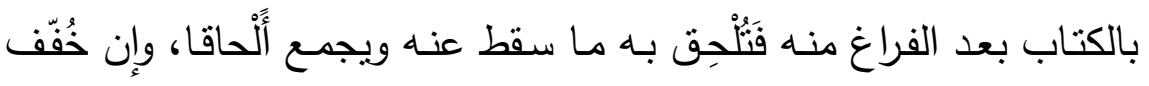

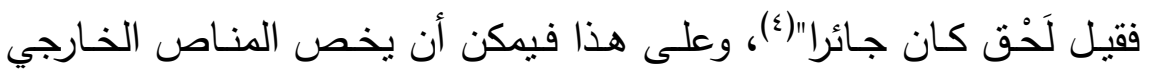

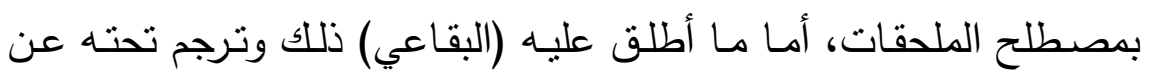

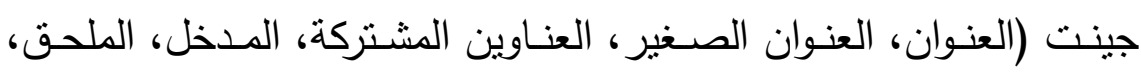

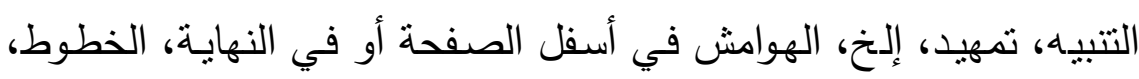
التزينات والرسوم) فيمكن أن يخص بمصطلح العتبات، وهو أوفق لها لغوياً

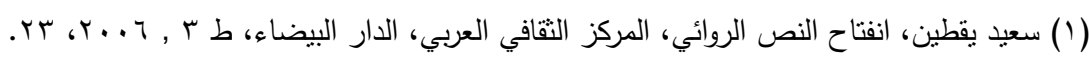

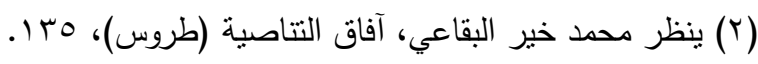

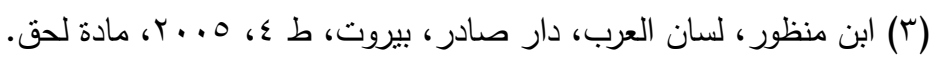

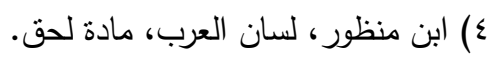

$$
\begin{aligned}
& -111-
\end{aligned}
$$




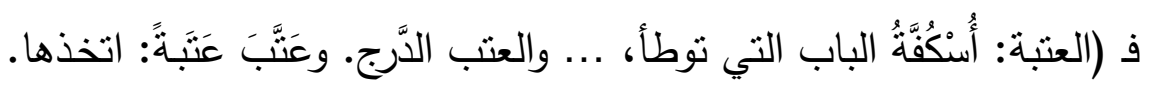

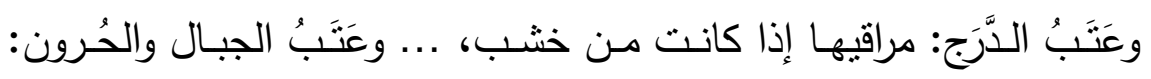

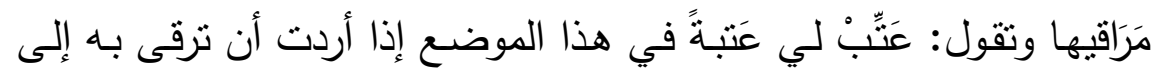

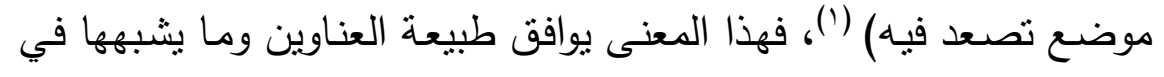

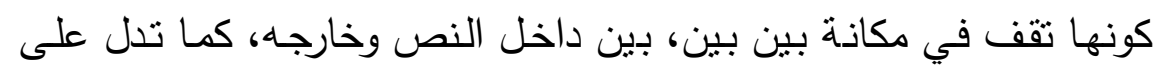

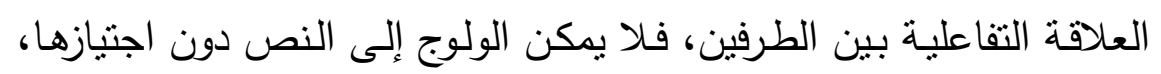

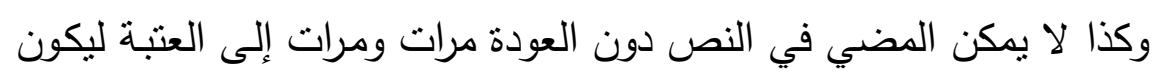

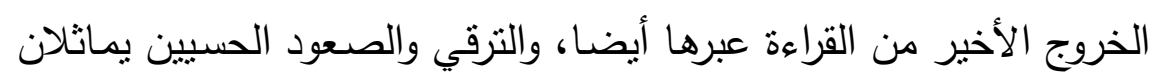

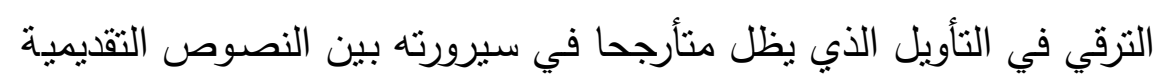
والنص الأصلي. - النيل

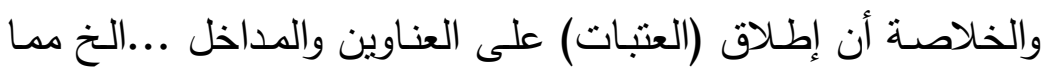

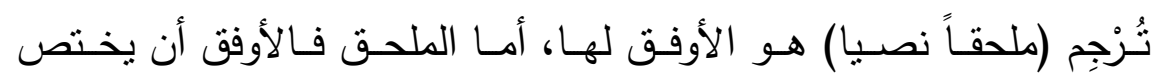

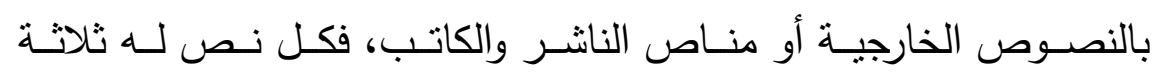
عناصر :

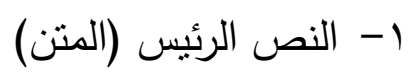

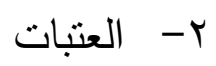

r- ب النصوص الملحقة (المناص الخارجي/ الفوقي)

وسيقتصر البحث على دراسـة العتبـات وتفاعلهـا مـع نصديا الرئيس

عبر الروائي، متخذا من رواية "المبراث" لـ " سحر خليفة" نموذجا للإراسة. ينكون البحث من مقدمة وتمهيد وخمسة مطالب: 
التمهيد: ويشير إلى قراءة النص في ضوء سيمياء التأويل، كما يشير

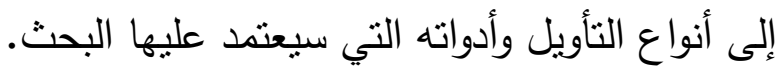
المطلب الأول: العنوان ويشمل: البنبة والوظيفة. المطلب الثاني: عناوين الأجزاء. المطلب الثالث: الغلاف وينظر إلى الخط وطريقة رسم عنوان النص ولوحته النهاه

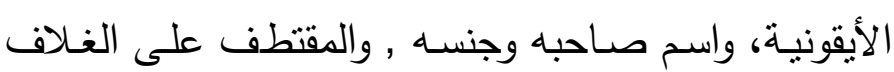

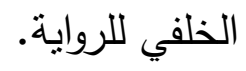

المطلب الرابع: الإهداء وصيغته والمهدى إليه وعلاقته بالنص وجنسه. المطلب الخامس: العنوان من البنية السطحية إلى العيقة. 
العمليـة التأويليـة" اسـتراتيجية قرائيـة هـفها إقامـة حـوار مــع العلامــة -الآخر -حتى يتم فتح ممر وتأسيس فسحة لممارسة الحوار وتفاعل الخبرة

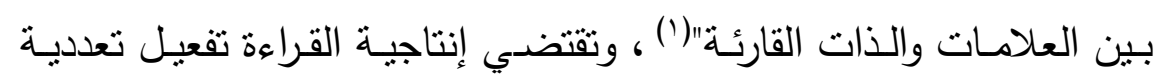
النص، عن طريق تفكيك الأنساق النصية؛ ذلك أن اشتغال النظام السيميائي التبادلي رهين بتدخل القارئ الذي يقوم بعملية الربط بين الدلائل حيث يغدو

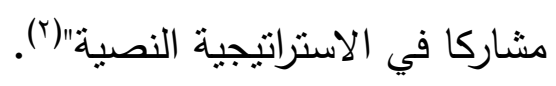
القراءة التأويلية للسرد تتطلق من العلامات إلى ثقافة المتلقي، وقدرته

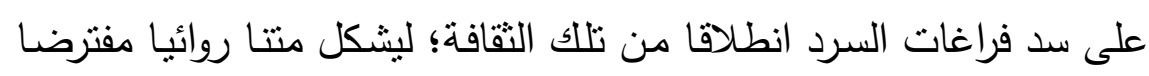
وموازيا عبر العوالم الممكنة، وحينئذ سينصب التركيز في المتن الحكائي

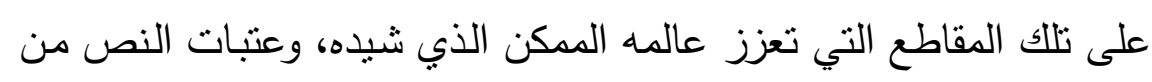
أهم العلامات التي تسهم في الكثف عن تيمته وتأويليه.

يرى البعض أن غاية التأويل هي" الإحاطة بالدلائل الأصلية للعمل؛

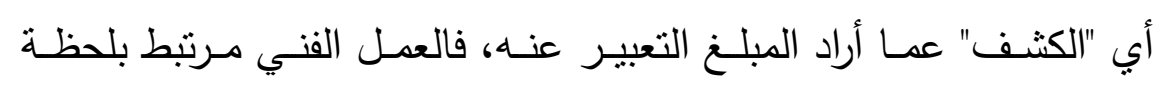

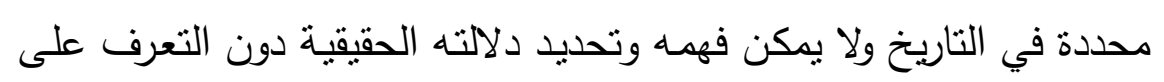

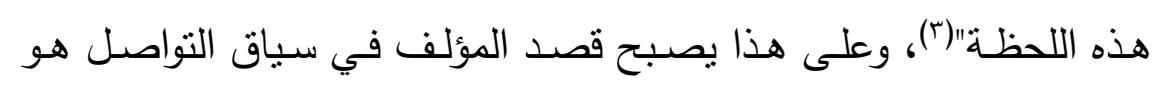

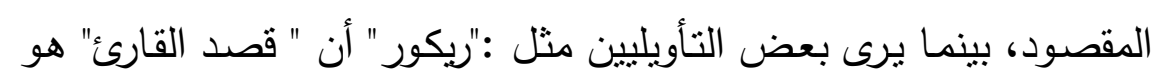

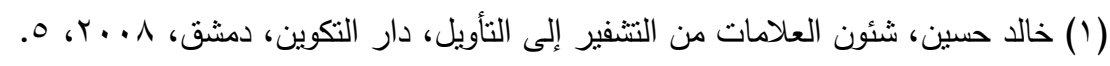

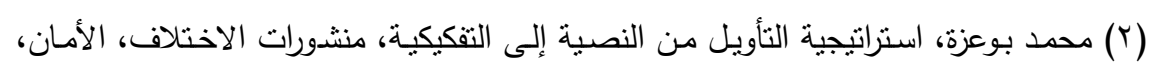

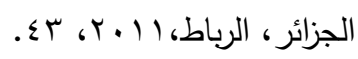

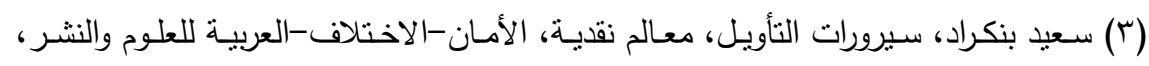

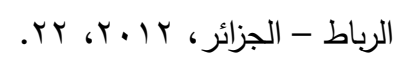


بغيـة المؤول، فيستغنى بذللك عن قصد المؤلف للاحتمـاء بقصد "القارئ

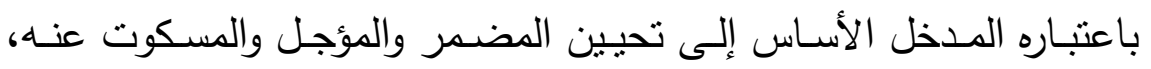

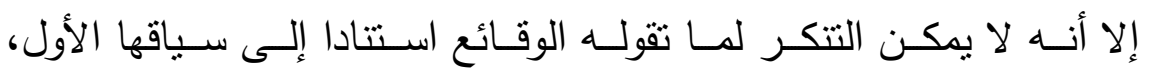

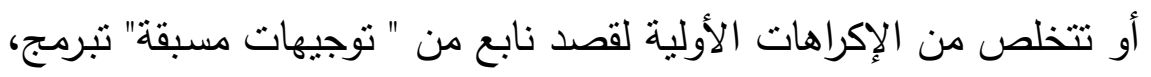

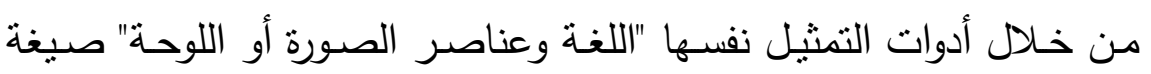

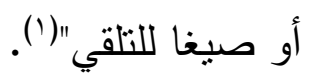
وبناءً على ما سبق يمكن رصد نوعين من الثأويل:

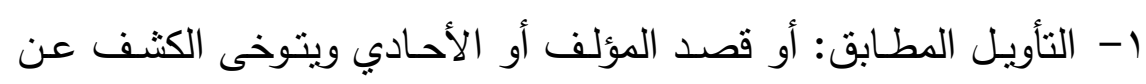
مقاصد الكاتب فيطابق بينها وبين مقاصد النص.

r- الثأويل المفارق: وهو يسلم بتعدد دلالات النص، مؤذنا بأن مقاصد

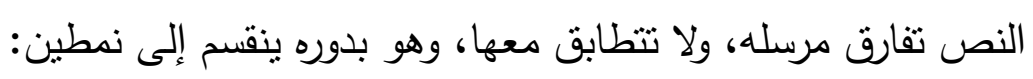
أ- التأويل المتتاهي: وهو يرى أن تعددية دلالات النص محدودة، تحكمها

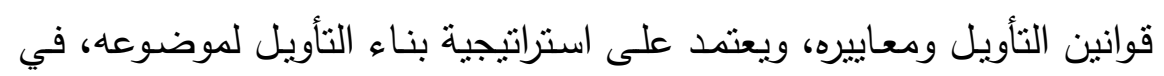
سيرورة سيميائية، تتنهي بتفضيل مدلول محتمل وترشيحه في سياق معين. ب- التأوبل اللادتتاهي: وينظر إلى تعددية الدلالات على أنها تعددية

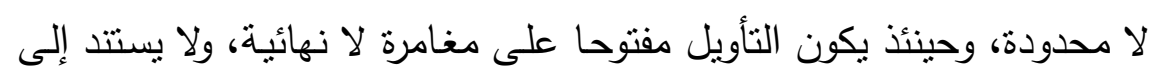

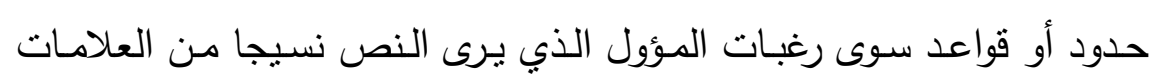
واللاتحديدات، لا يوقف انفجارها الدلالي أية نخوم (؟).

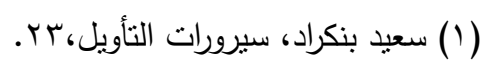

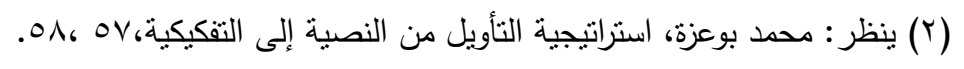




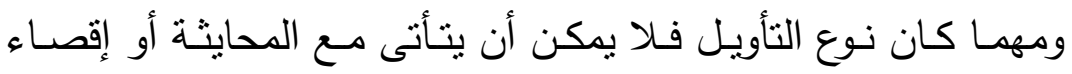

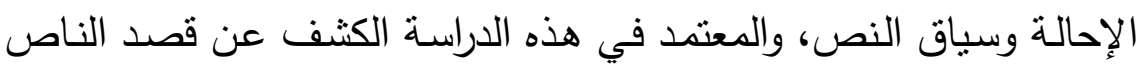

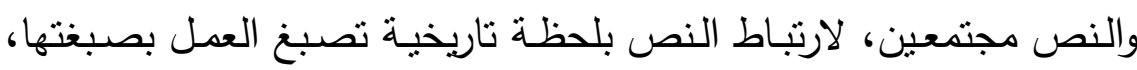

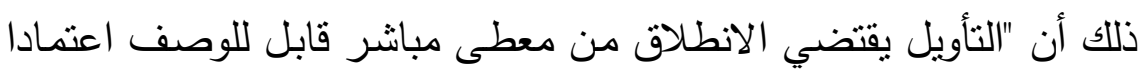

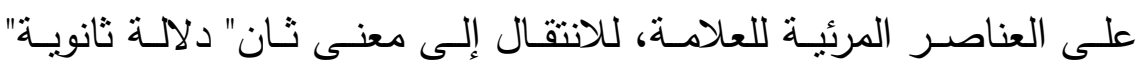
يستدعي تعبئة معرفة تثترط إعادة تتظيم العمل استتادا إلى علاقات جديدة

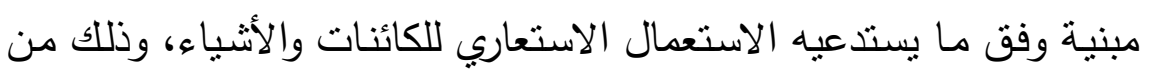
أجل الوصول إلى تحديد المضمون الأصلي للعمل الفني"( (). 


\section{المطلب الأول: العنوان الرئيس وعناوين الأجزاء$$
\text { - - العنوان : البنية -الوظيفة }
$$

العنوان بؤرة إثـعاعية، ومرسلة ذات اتجاهين، فهو مرسل ومستقبل

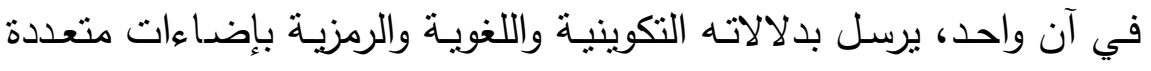

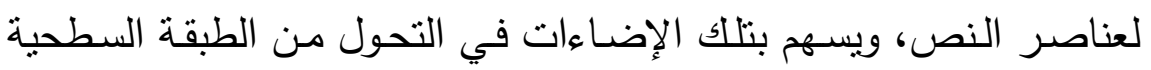
إلى البنية العميقة للنص، كما أنه يستقبل من الأخير بكل عناصره الفنية

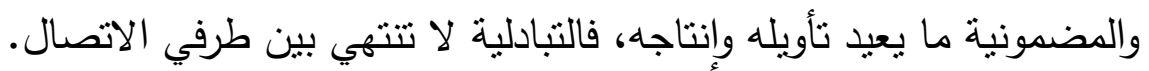

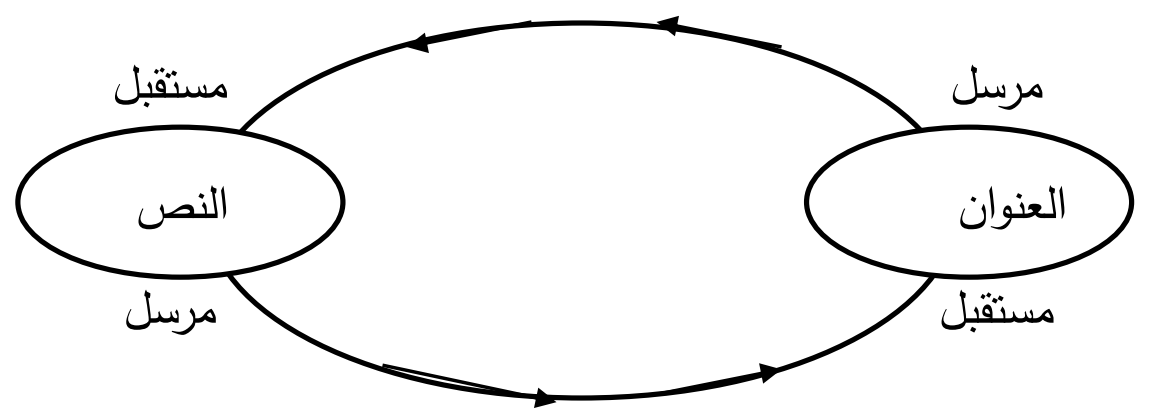

" الميراث "على المستوى التركيبي اسم معرف يشغل موقع المسند إليه

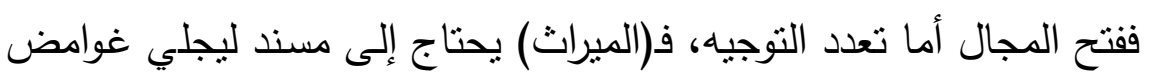

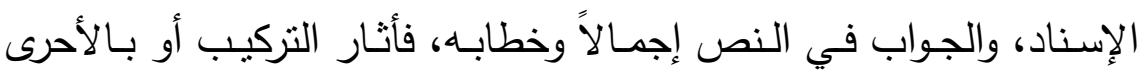

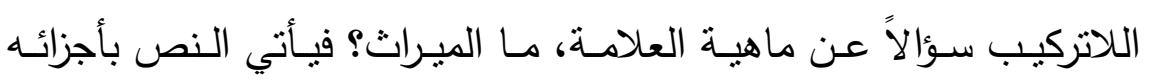

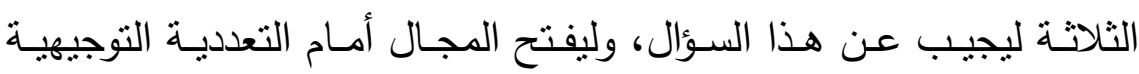

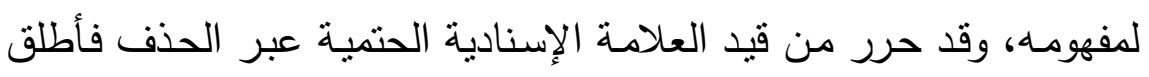

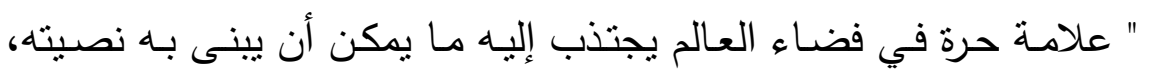

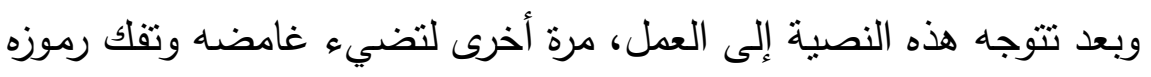

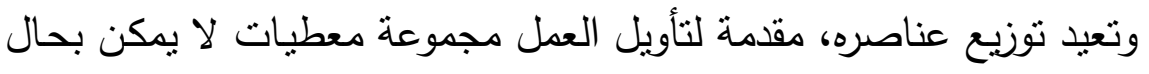


من الأحوال بناء نصيته بدونها" (').

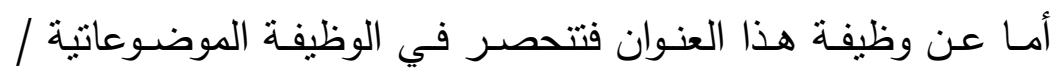
الدلالية ، وهي الوظيفة التي يقول العنوان عن طريقها شيئا عن النص، هي

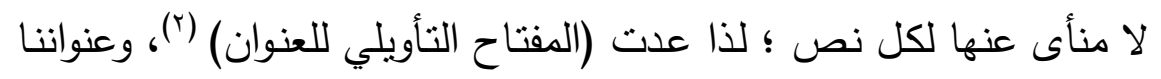
هنا موضوعي يجعل النص مرجعا له باعتبار دلالته وتركيبه النحوي، فهو

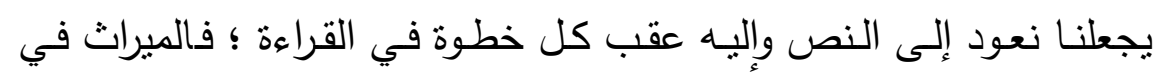

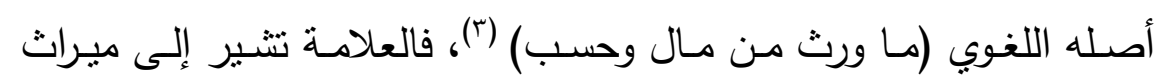

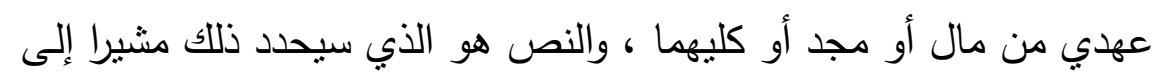

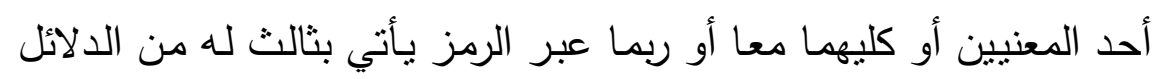

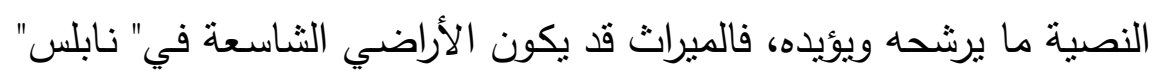

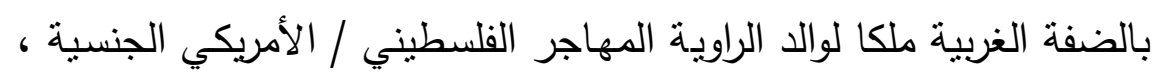
والتي تؤول بالميراث إلى ابنته الوحيدة وإخوته، وهذا الميراث يتتازعه كثيرون

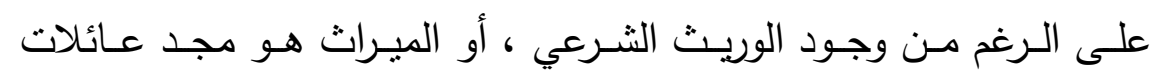

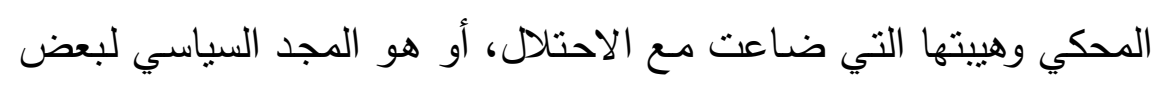

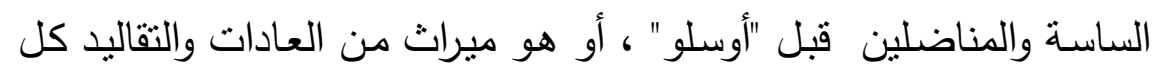

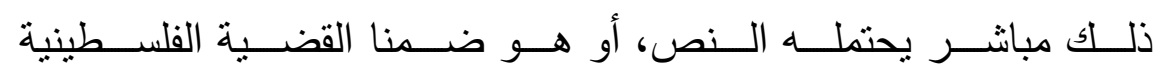

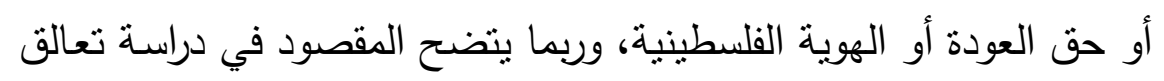
العنوان مع البنية السطحية والعميقة للنص.

( (1) محمد فكري الجزار ، العنوان وسيموطيقا الاتصال الأدبي، الهيئة العامة المصرية للكتاب، القاهرة، 1991، 111 11.

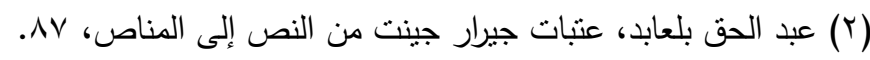

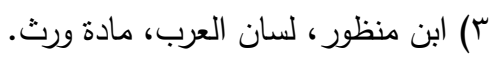




\section{- عناوين الأجزاء}

قراءة العناوين الفرعية في تفاعلها مـع فصولها أو أجزائها هي قراءة تفكيكية للعنوان الرئيس، ولتلك العناوين وظيفة موضوعية كوظيفة العنوان الرئيس الموضـوعية، بـل هي أدخل في تلك الوظيفة ؛ فالعنوان قد يحمل وظيفة الإثهار أو التعيين بالإضـافة إلى وظيفته الموضوعية أمسا عناوين

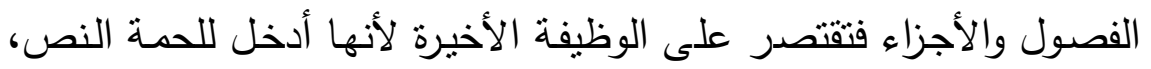

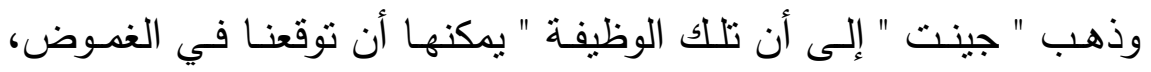

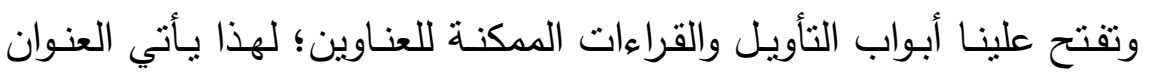

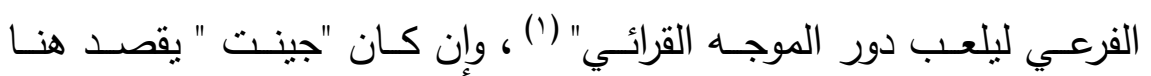
بـالعنوان الفرعـي؛ العنـوان التـالي تحــ العنـوان مباشــرة كعنـوان شـارح

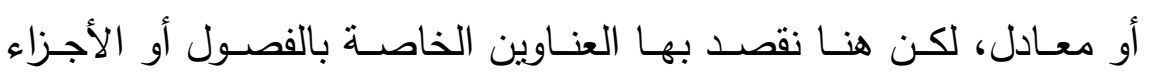
باعتبارها تفتيتا أو تفكيكا لكلية العنوان الرئيس، فهي عناوين فرعيـة تلون على مضدونه وتعيد كلا مع فصله أو جزئه الإرسالية ذات الاتجاهين التي لئي يؤديها العنوان الرئيس مع مجمل النص.

تتكون الرواية من ثثلاثة أجزاء عنونت على التوالي بـ (بـا ميراث -

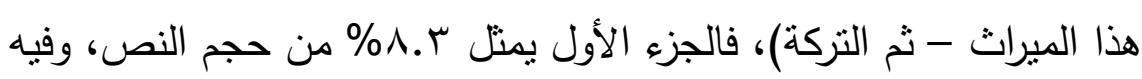

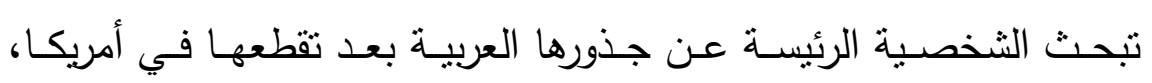
ويساورها إحساس بافتقاد الهوية (كانت "نحن" تؤلمني، فما معنى نحن؟ ومن نحن؟ نحن الأمريكان؟ أنا لست أمريكية. "من أنت إذن؟" سألتني يوماً حين

(1) محمد مفتاح، مجهول البيان، توبقال، الدار البيضاء، ـ991، Y 11. 
كررت ذللك القول. لم أقل عربية لأنني لست كذلك. من أنا إذن؟ بالرغم من

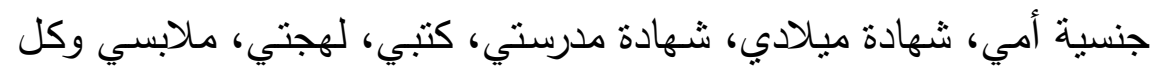

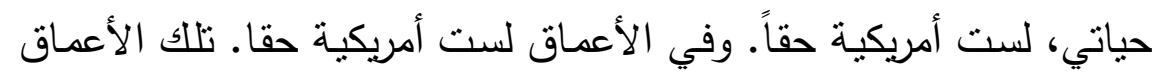

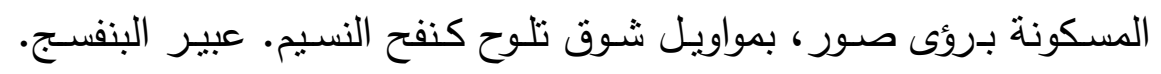

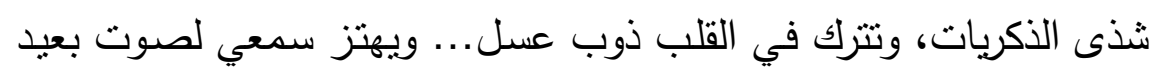

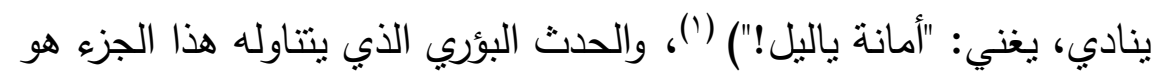

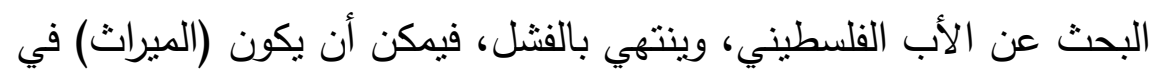

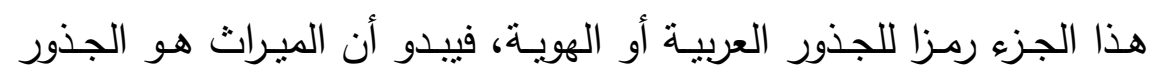

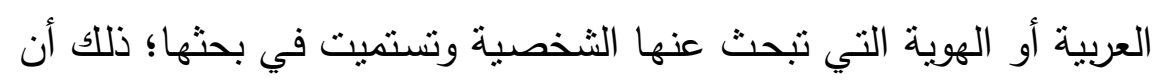

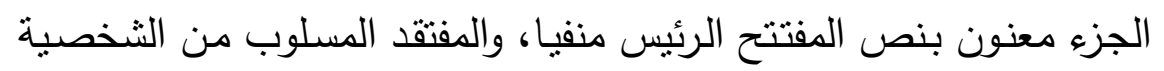
حسب مدار هذا الجزء هو افتقاد الهوية كما صرحت في ختامه (أضعت التهن الخيط أضعت الأهل والوالد، ولا أعرف بأبيّ ديار ! فماذا أفعل؟) (؟).

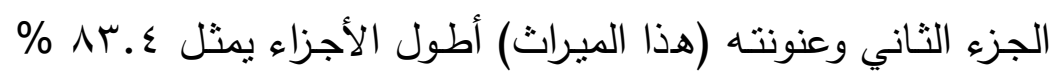

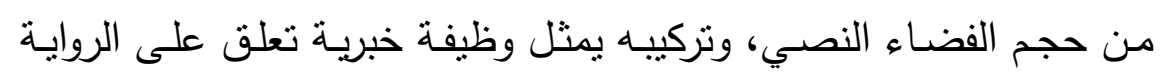

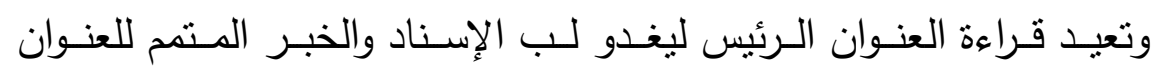

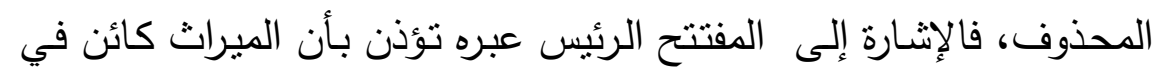

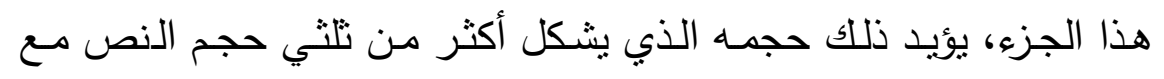

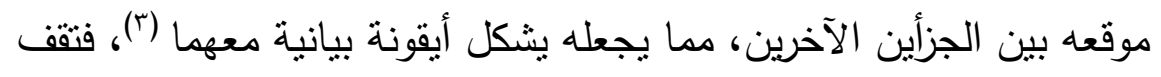

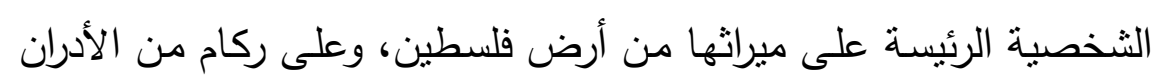

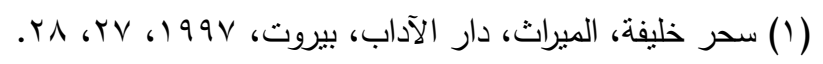

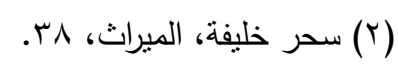

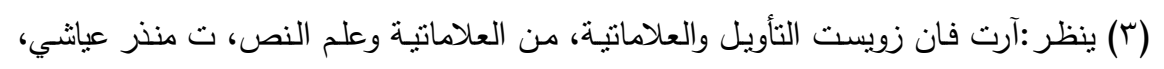

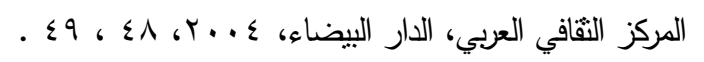




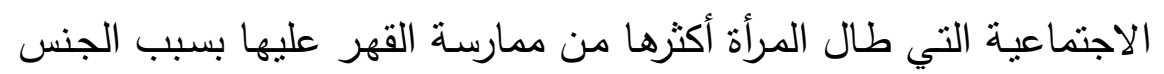

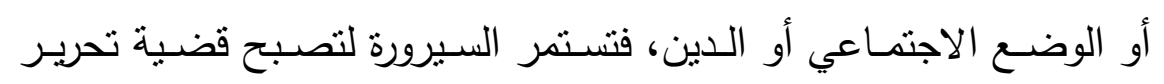

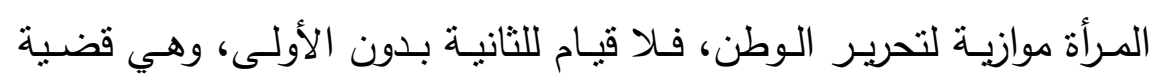

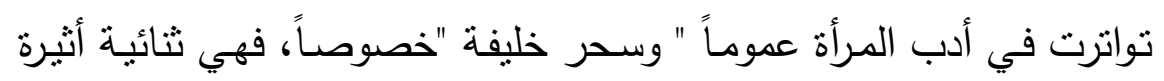

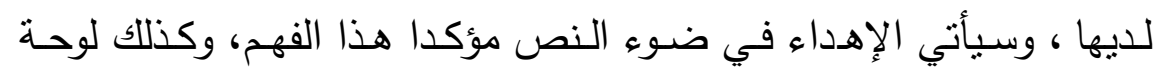

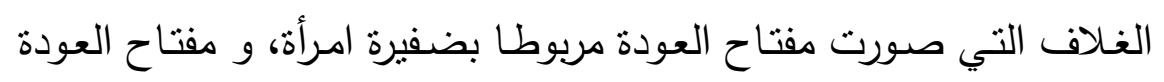

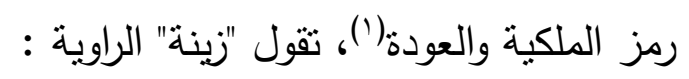

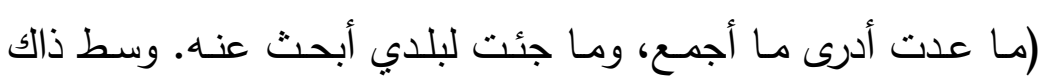

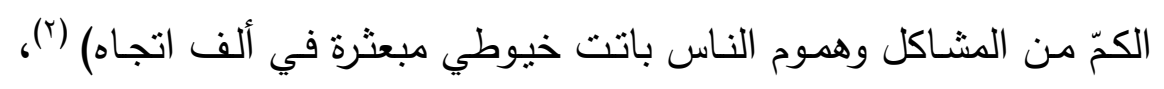

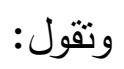

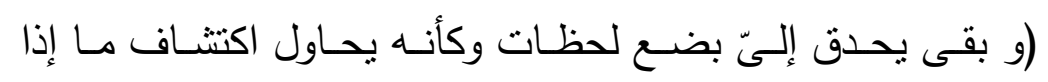

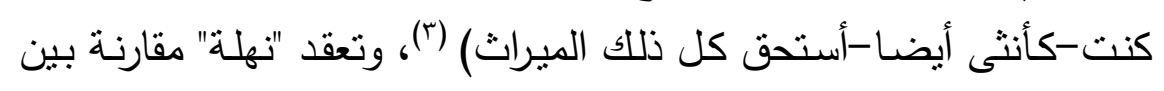

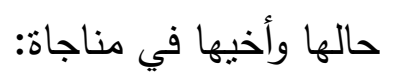
(ليش أغيب ما حدا بيسأل؟ ليش لما قعدت في الطوز سنين عمري

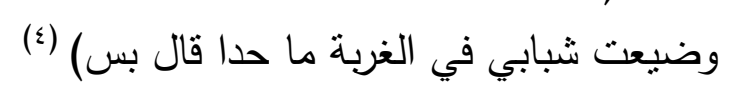

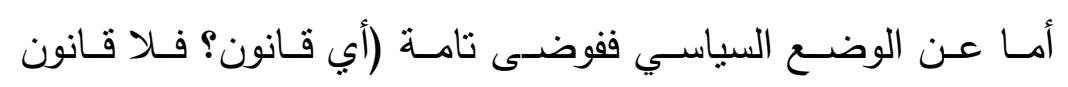

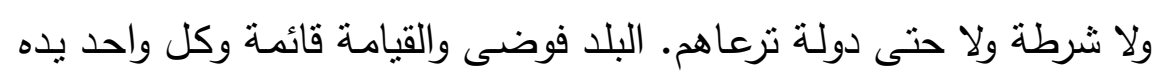

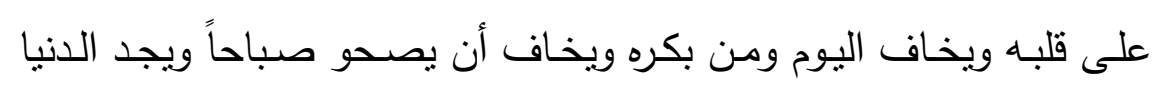

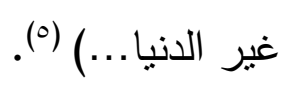

(1) مفتاح العودة من أهم الرموز الفلسطينية، وقد رفع أول مرة رسميا في الذكرى الخسين للنكبة.

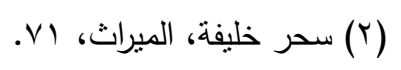

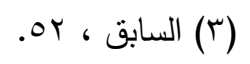

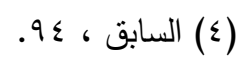

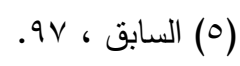


وهكذا صار موضوع أو مدار هذا الجزء يمتزج فيه الواقع السياسي

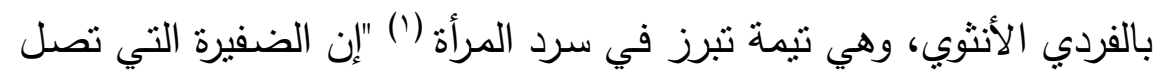

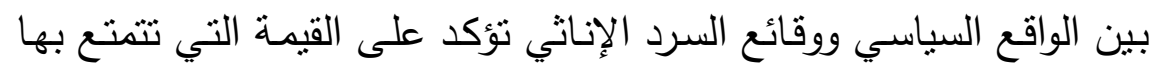

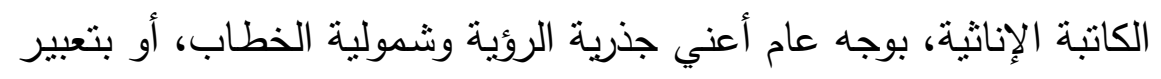

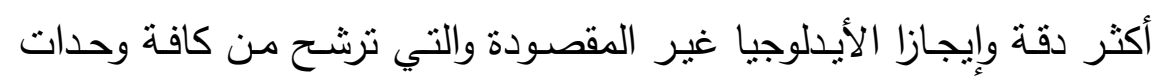
السرد" (؟).

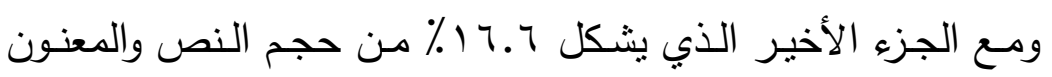

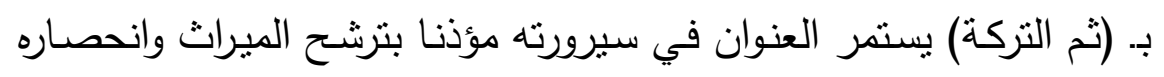

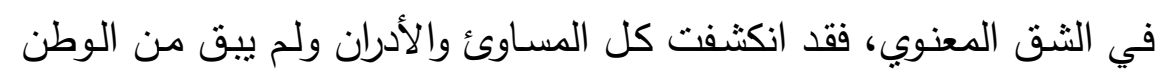

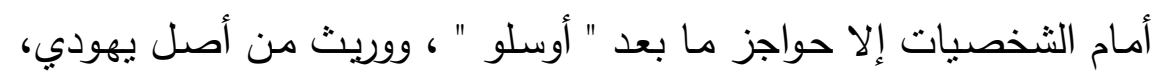

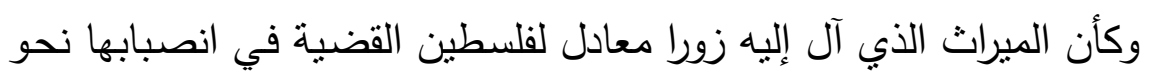

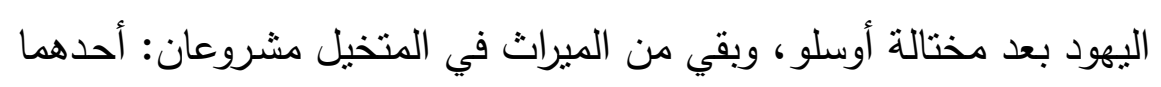

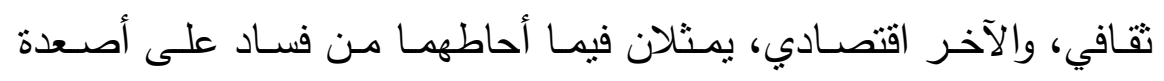
مختلفة وانتهائهما بالفشل رمزا لمستتقع الاتفاقية.

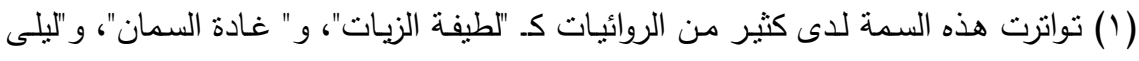

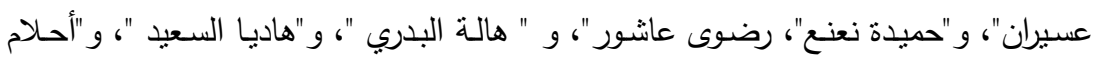

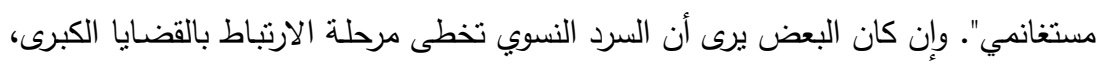

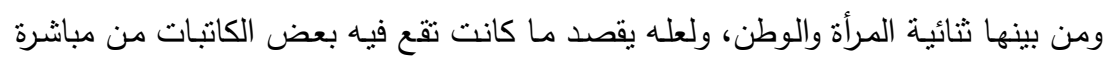

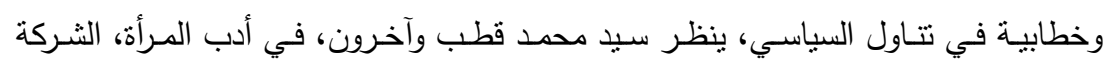

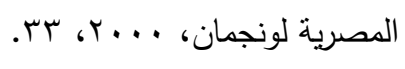

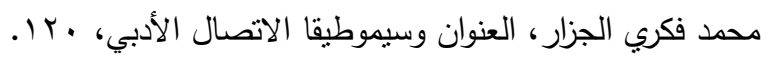




\section{المطلب الثاني: الغلاف ولوحته}

الغـلاف هو الفضـاء الحامل للعنوان، وفصله عنه حين الدراسـة

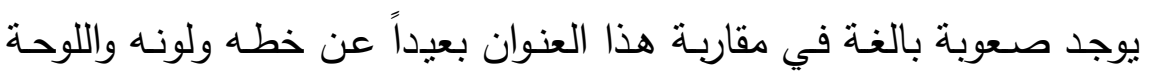

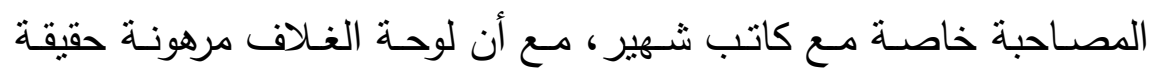

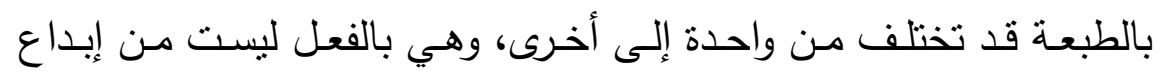

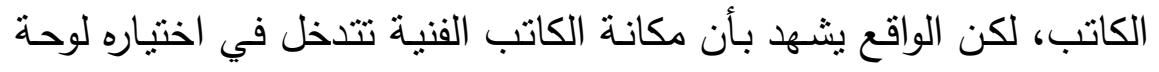
تعبر عن مضمونه دالة عليه إلى حد كبير.

إن المقاربـة لا نسعى لتفسير النص باللوحسة وإنما العكس، وفضـاء

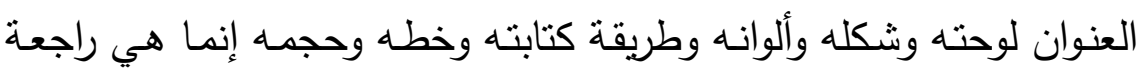

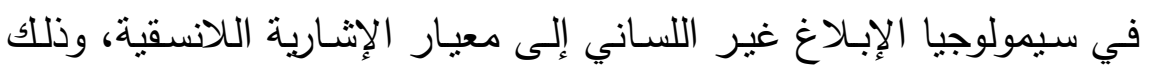

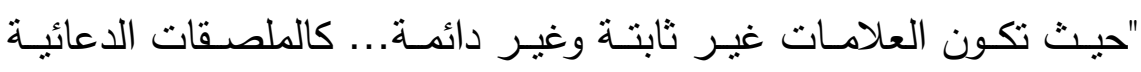

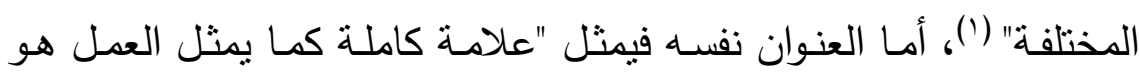

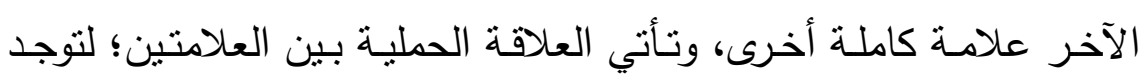
علامة وسيطة بين الاثثتين" (؟).

دال (الميـراث) مــع الحذف التركيبي يفتح البـاب أمسام التـأويلات

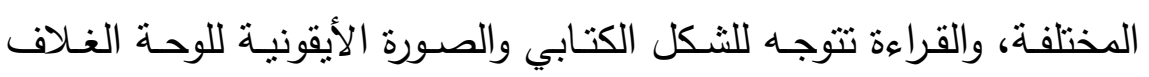

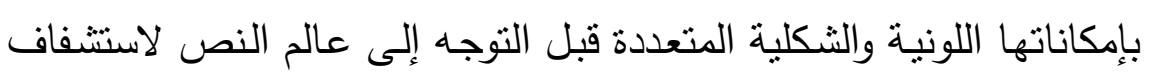

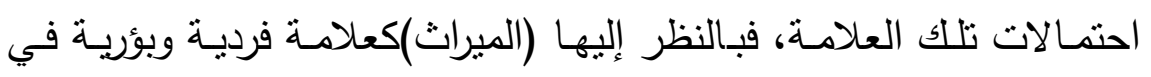
فضاء النص وفضاء الغلاف يمكن استجلاء أو كثف بعض غموضها من

(1) محمد السرغيني، محاضرات في السيمولوجيا، دار الثقافة، الدار البيضاء، 19AV.

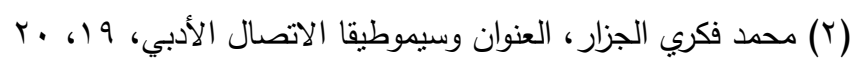


طريقة الكتابـة، وربطهـا بوظـائف العلاهـة الاجتماعيـة والثقافيـة في العـالم

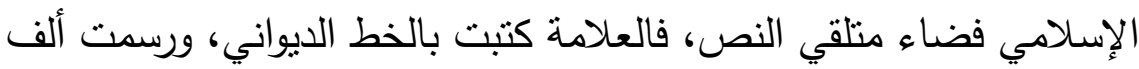

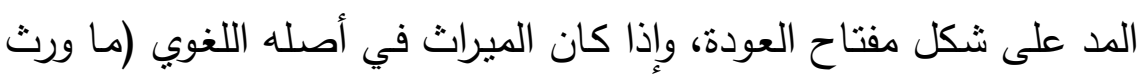

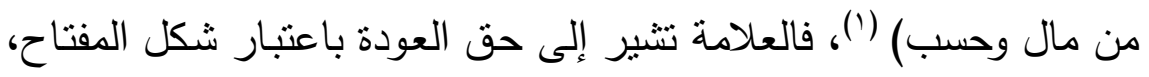

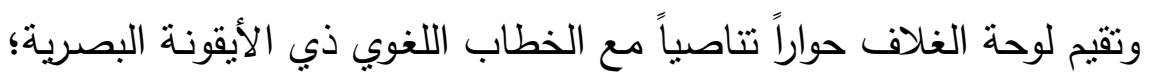
ليتحاور خطابان متغايران في نمط التشكيل ولبناته، ولكن الثاني التتكيلي

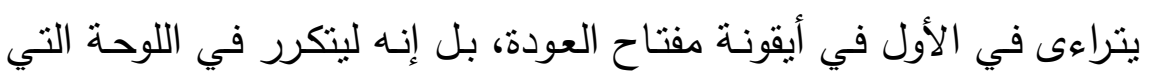

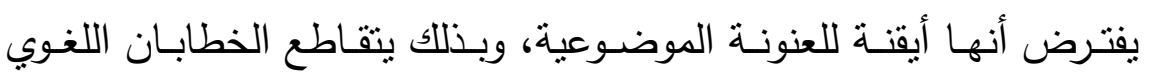

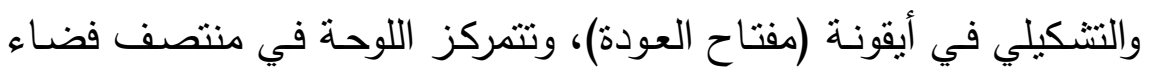

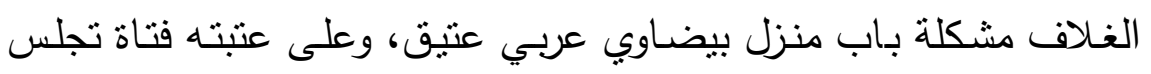

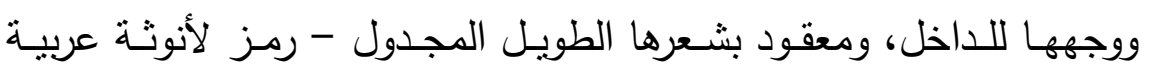

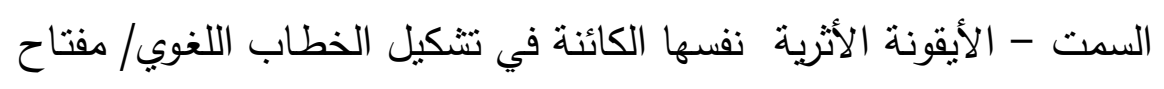

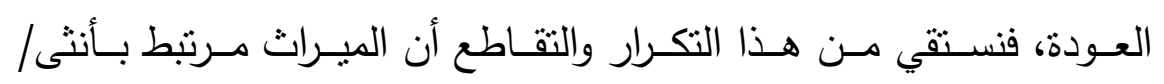

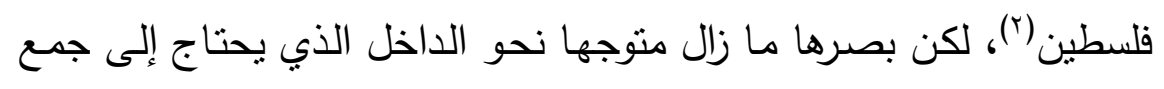

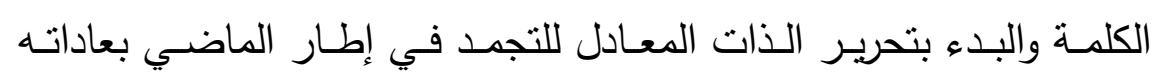

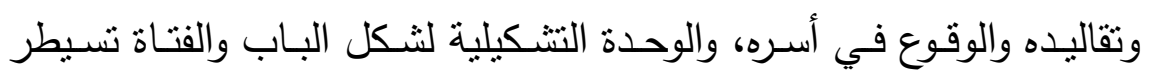

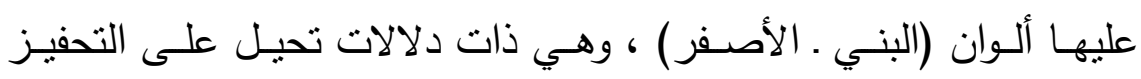

(1) (1) (بن منظور ، لسان العرب، مادة ورث.

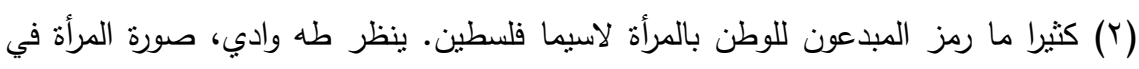

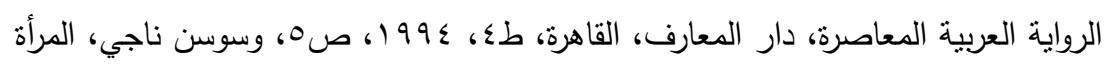

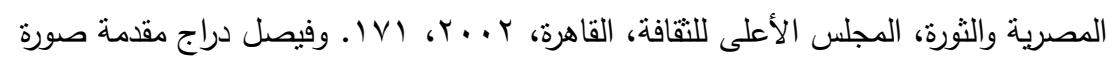

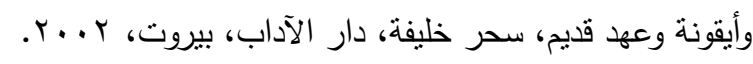


والتهيؤ للنشاط والخوف من المجهول(")، ومن ثم تتكثف بعض غوامض الخش الخطاب اللغوي المختصر (المبراث) في أنهـ يشمل مـالا تليدا/ حقا قديما ثابتا ثبوت الميراث يخالطه الأسى والإشكالات.

أيقونة (مفتاح العودة) تصرف الذهن مـع التكرار إلى التوكيد الرامي

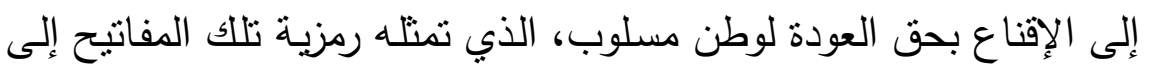

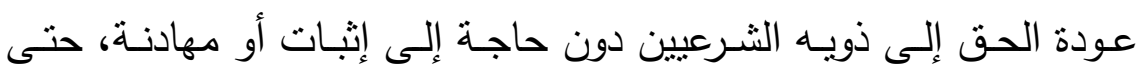
يجذر التكرار لتلك الأيقونـة، لتغـدو سـلاحا مـن أسـلحة المقاومـة الثقافيـة المناهضــة لضياع الحـق السليب، الذي يـراهن الاحتـال على نسيانه مـع

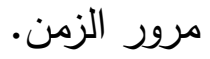

والتحديد الجنسي للنص مكتوب في الطرف الأيسر للغـلاف مواز

للعنوان الرئيس في فضاء مستطيل أخضر اللون؛ ليكون لطبيعة دلالة اللون

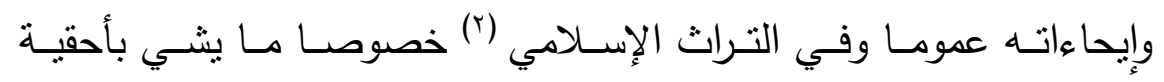
الميراث، والوقوف في جانب الدفاع , وهو وإن كان سلبيا ففيه استشراف لعودة الحق على يد جيل الثباب، إذ يرتبط اللون الأخضر " بمعاني الدفاع والمحافظة على النفس...كما أنه يمثل التجدد والنمو والأيام الحافلة للشبان". 
يرد اسم الكاتبة تحت العنوان (سحر خليفة) مما يغري وضع اسمها

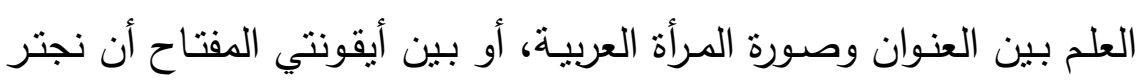

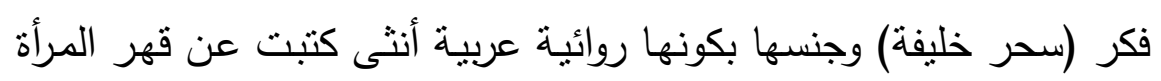

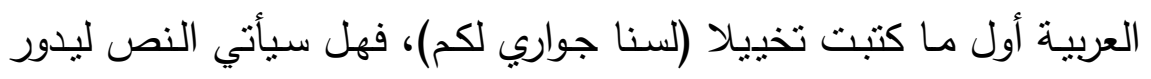

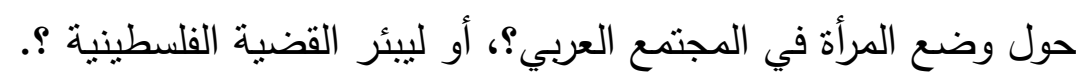
ثم يأتي المقتطف الموضوع على الغـلاف الخلفي (وجلست وحدي

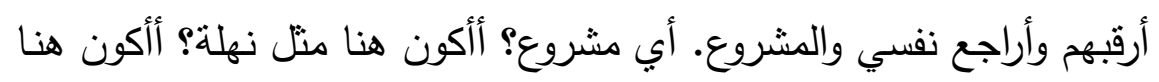

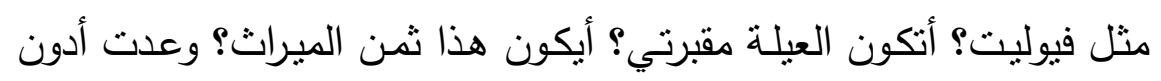

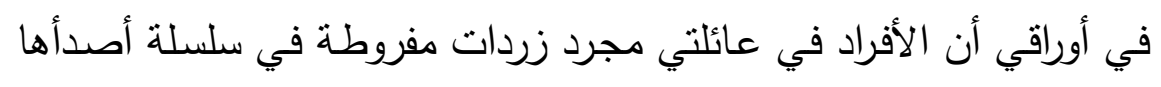

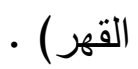

فالمقتطف مناجاة للثخصية الرئيسة الباحثة عن ميراثها، وقد وضعت

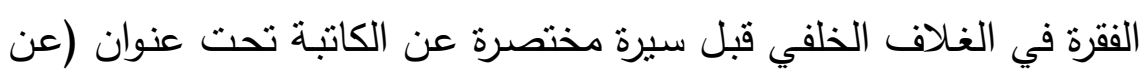

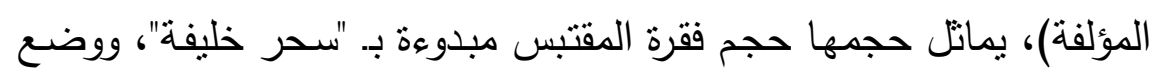

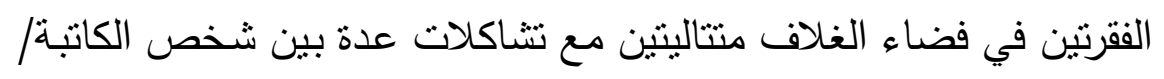
سحر خليفة وشخصية البطلة/زينة ساردة المقتطف مكن من إجراء مقابلة

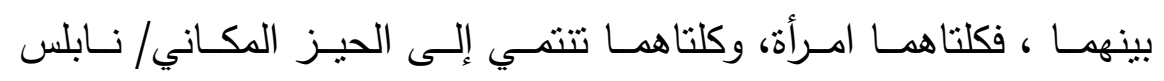

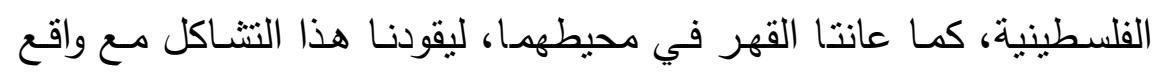

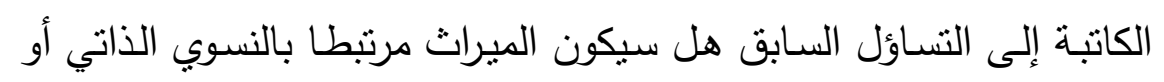
بالقضية الفلسطينية؟ 


\section{المطلب الثالث: الإهداء}

يشكل الإهداء عتبـة مهمـة من عتبـات النص، ويمثل المهدى إليه بؤرة هذه العتبة والعلامـة الفارقة في صياغتها، والأقدر على الوصول إلى الاهلى

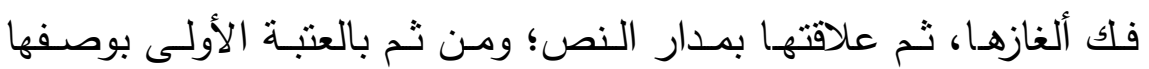
موضوعية الوظيفة، فتحديد جنس المهدى إليه وطبيعة علاقته بالكاتب، ثم

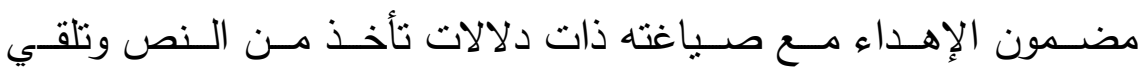
بإثعاعاتها عليه في آن واحد، هو كائن في صفحة بيضاء يتوسطها ليجعل كل الإشارات المجاورة تتعاطى معه لنتي بما يتعالق مع النص بالضرورة. "الإهداء إلى الحفيدة الصغيرة سحر الديسي عساها تكتثف الميراث ...

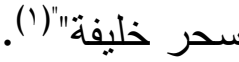

الإهداء يبدو خاصـا في توجهيه للحفيدة، لكن جنس المهدى إليه وكونها سمية الكاتبـة مـع ورود العتبـة الأولى (الميراث) بلفظها يفتح الذهن والجسر الدلالي ممتد بين العنوان والنص في محاولة لمقاربـة هذا النص الاختزالي والنص الأساسي "مادام هذا المهدى إليه يحوز قصب السبق في

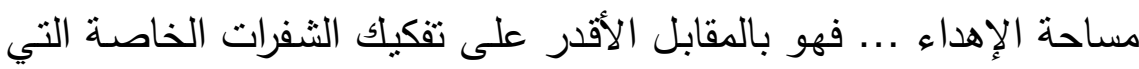
يتضـنها الإهداء أولا، والعمل الأدبي بعد ذلك.... فهو الذي يراهن عليه الاهـ الكاتب ـ المهدى في تحقيق ذلك الإنصات الدقيق لنبضات النص والإصـاخة 
الصادقة إلى همساته غير البريئة التي لا تخلو من دلالات، تارة جهيرة وتارة

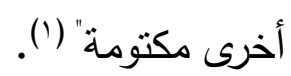

وبنـاءً عليـه فالمهدى إليـه (سـحر الحفيدة) فتـاة فلسـطينية كراويـة النص، تتمنى الكاتبة أن تكتثف سميتها الميراث كما تبحث عنه البطلة، إذن فالميراث المعني مخبوء يحتاج من يميط عنه اللتام، ولماذا الحفيدة وهي

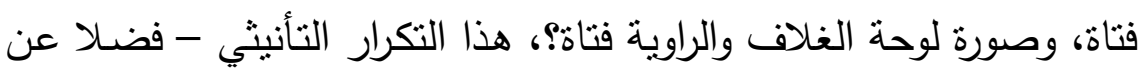

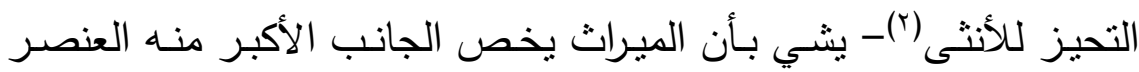

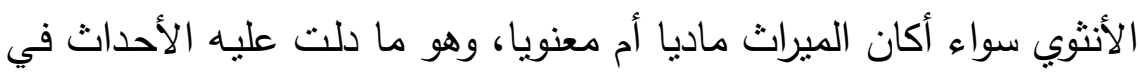

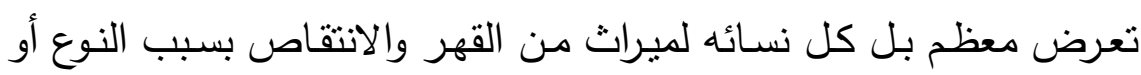

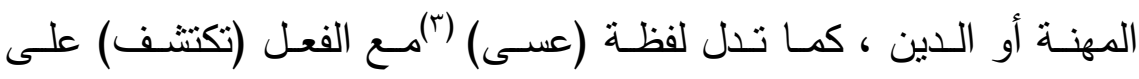

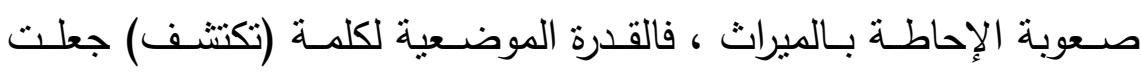
الميراث اقتضـاءً معدى ومجهولا يحتاج من يميط اللثام عنه، ويبذل الجهد

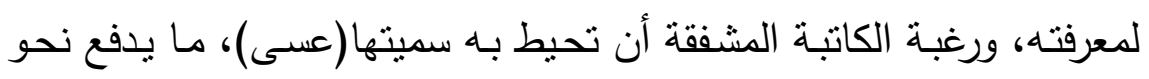

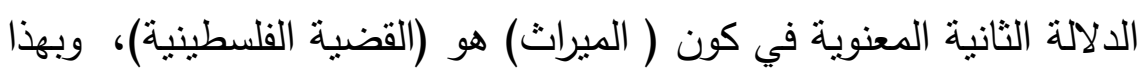

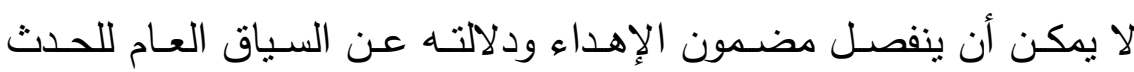

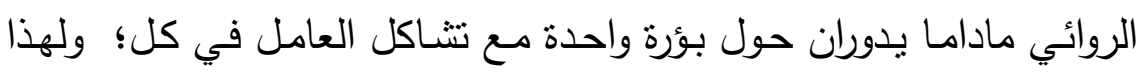

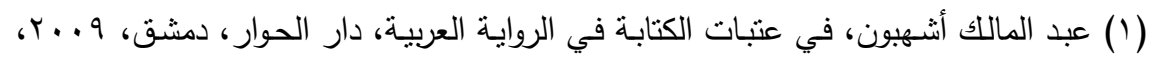

$$
\text { r.r. r. r. }
$$

"الانحياز للصوت النسوي" مصطلح أطلقه د. محمد عبد المطلب في قراءة السرد النسوي، النسا،

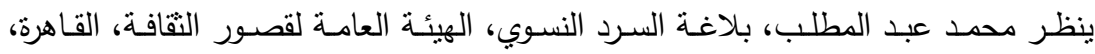




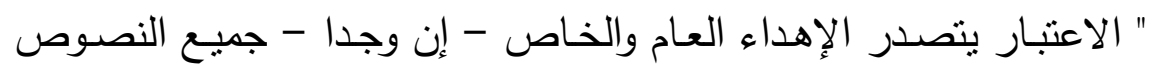

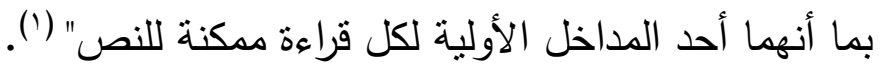

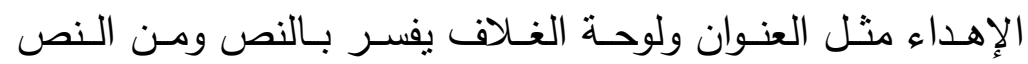

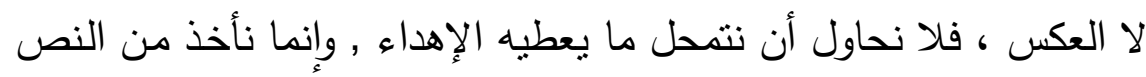

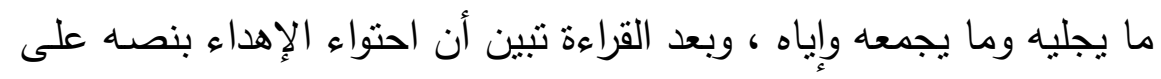

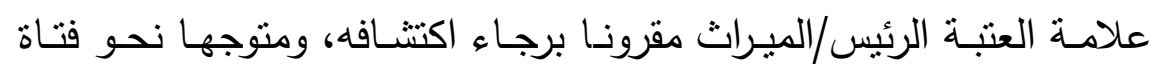

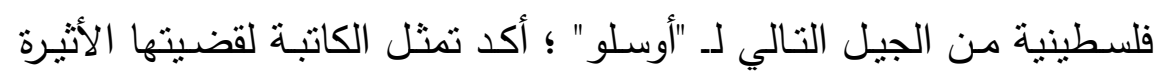
والقديمة في أعمالها الروائية ، وهي الربط بين تحرير المرأة من نير العادات

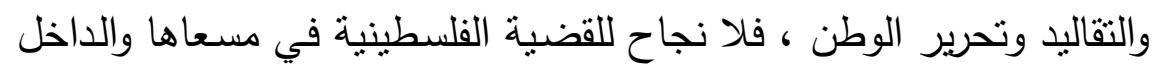
الاجتماعي يمور تحت ركام من عطن التقاليد والعادات المجحفة للمرأة . إن نوجه الإهداء نحو (الحفيدة) هو توجه استشرافي وتحفيزي نحو

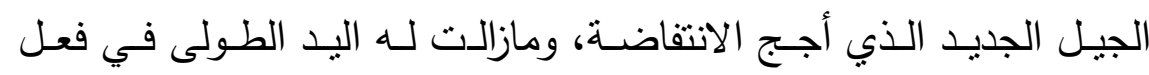

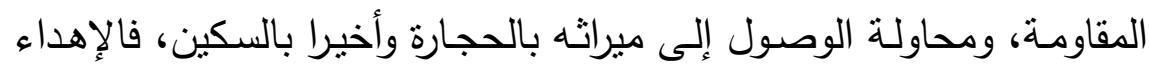
أكثر العتبات ارتباطا بالواقع الخارجي، فجعلت منه الكاتبة معبرها نحو عالم

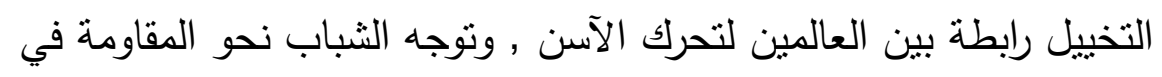

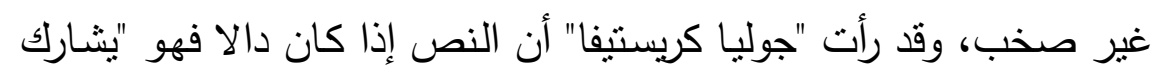

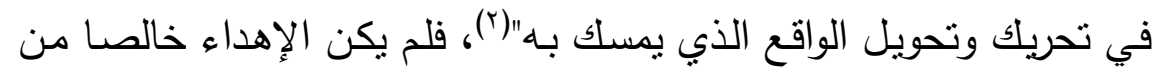

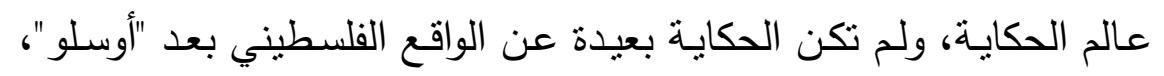

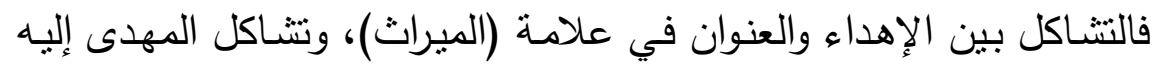

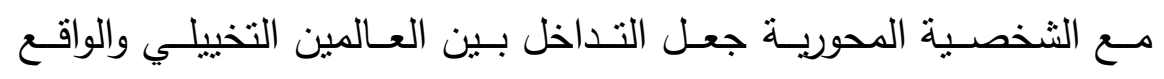

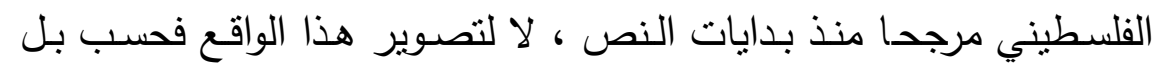
لمحاولة تغييره والاعتراض عليه.

(1) عبد الفتاح الحجمري، عنبات النص البنية، الرابطة، الدار البيضاء، 99 (1)، . ب.

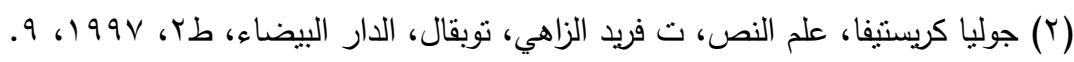




\section{المطلب الرابع: حوار العنوان مع النص/}

من البنية السطحية الى العميقة

\section{العنوان والمحور}

المحور أو المدار مفهوم تداولي استخدم استخداما يكاد يكون مساويا لمفهوم

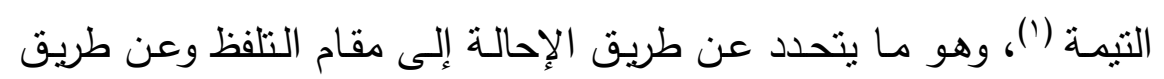

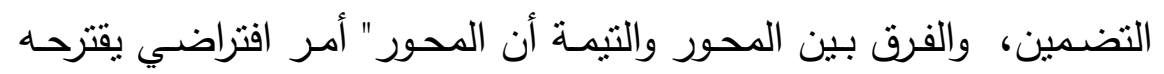

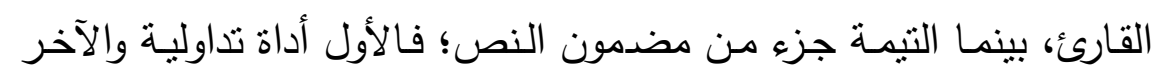

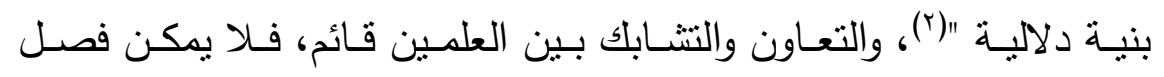

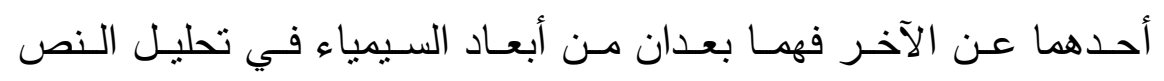
الأدبي (r)، ف" علاقة التيمة تتحدد بالمحتوى لا بالقارئ، تسمي وتخبر وتعبر

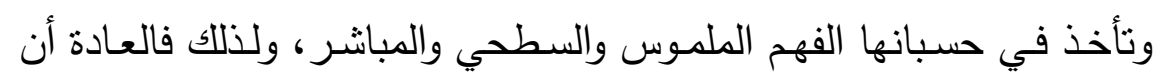

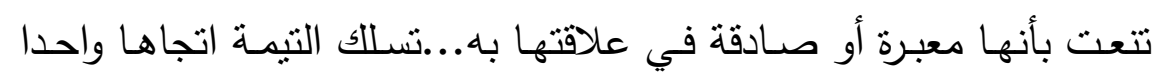
نحو المحتوى، ولا تدير بالا للقارئ، تولا من المحتوى؛ لتعود إليه وتبقى في به بهايه

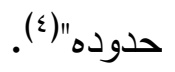

(1) فضل"إيكو" استخدام مصطلح المدار أو المحور دون التيمـة كي لا يلتبس مع مصطلح

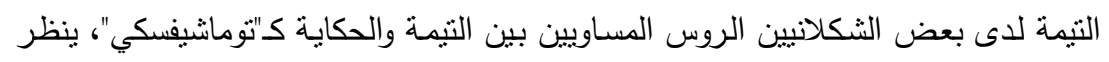

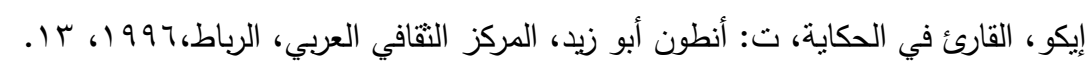

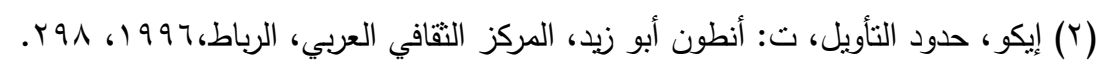

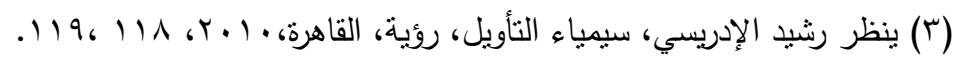

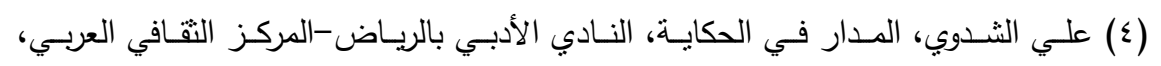

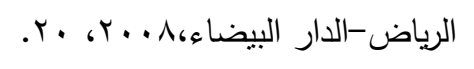


(الميراث) عنوان مخاتل في إمكانية امتحاح المحور أو المدار النصي

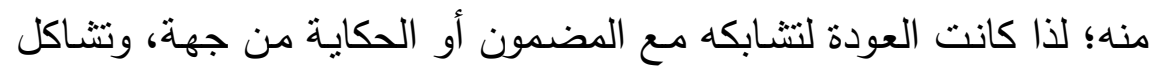

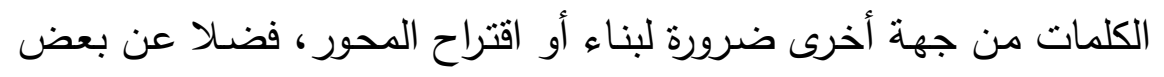
الملفوظات الضمنية أو الصريحة التي بثها السارد أو الثخصيات، فعلامهة (الميراث) كمفتتح رئيس تسهم في الكثف عن المحور المقترح حتى يمكن

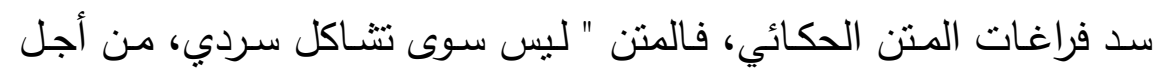

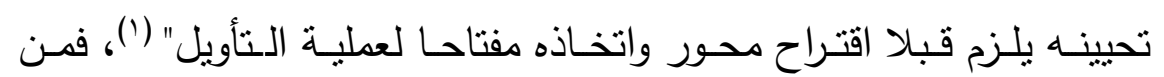

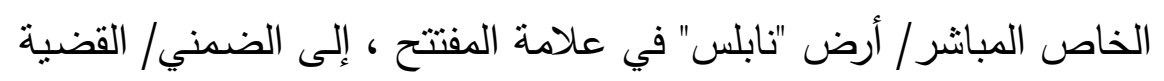
الفلسطينية بعد "أوسلو" يمكن اقتراح محور السرد الغالب:

" الحـق الفلسطيني التاريخي ومـا يسـتبعه مـن الهويـة"، فهو ثابـت

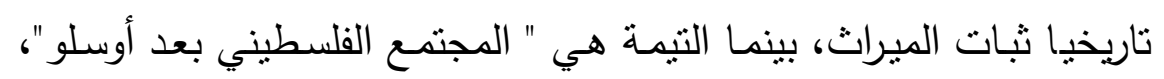
فمن خلال المدار يمكن إنتاج معنى النص.

من هذا المحور ننطلق صوب المنت الحكائي والخطاب المظهر لله

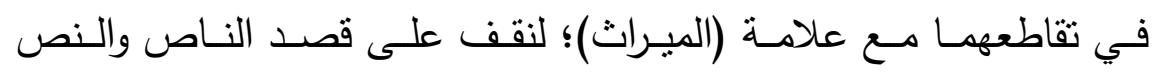
باستخراج ما يؤيد نصيا ذللك التأويل، والقصدية أو المقاصد تتطلب معرفة بالسياق والمساق الحافيين بالنص المدروس. مساق هذا النص بالنسبة لأعمال" سحر خليفة" السابقة مهم في تأويله وفق انسجام هذه المرسلات، تأتي رواية (الميراث) في الترتيب السادس من لأن روايات الكاتبة، تسبقها " لسنا جواري لكم"، وهي نسوية خالصـة -كما يبدو من علامات عنوانها- لم تتطرق للقضية الفلسطينية، ثم "الصبار"، و "عباد ولهي

(1) محمد مفتاح، مجهول البيان، دار توبقال، الرباط، ـ99 (1) Y II. 
الثمس"، و "مذكرات امرأة غير واقعية" و"باب الساحة"، وقد مزجت فيها بين القهر النسوي وقضية الاحتلال، مسـلة في كلٍ مرحلـة زمنيـة مـن تاريخ فلسطين منذ 19 1 حتى الانتفاضة الأولى، ثم كانت (الميراث) فوصفت ما بعـد " أوسـلو " مازجـة بـين النسـوي والسياسـي في ضـفيرة سـردية تظهـر الاجتمـاعي وتضـمن السياسي، ليعد تغييب القضية الفلسطينية في سطح

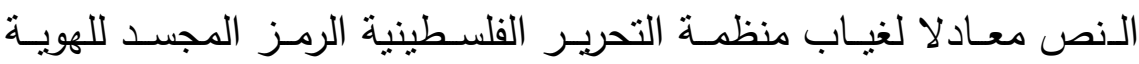
الجماعية للفلسطينيين لصالح السلطة المحكومة بسلطة الاحتلال. ومن مؤشـرات المـار المقترح عنوان الروايـة فهو المفتـاح التأويلي الأول، فعلامة" الميراث" -وإن وجدت في سياق الحكاية في دلالات مختلفة، غلبت فيها الدلالة المادية في ظاهر الحكاية- إلا أن تفعيل العنوان بدلالاته في تشابكه مع المعنى العميق يقتضي الذهاب إلى الهوية والحق الفلسطيني

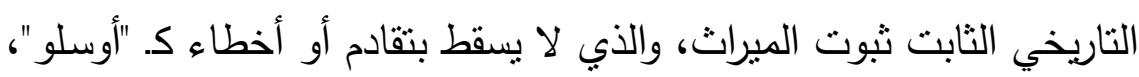
وهنـا يخايـل الإهـاء على خصوصـيته لوريثة خـارج المحكي مـن الجيـل الثالث، تشاكل شخصيات المتخيل بجامع الهوية الفلسطينية، ومن مؤشرات المحور أو المدار نتشاكل الصور المعجمية. 


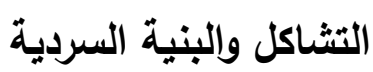

مفهوم التتـاكل أساسي في الثأوبل(1)، وبتتبع الصسور المعجميـة

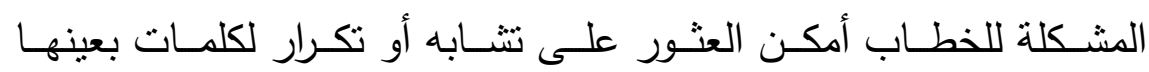

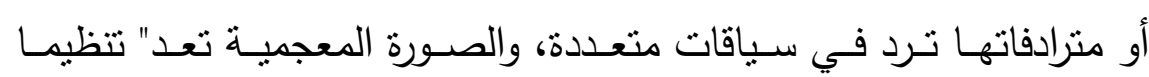

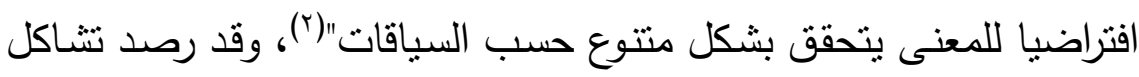
هذه الوحدات في برامجها السردية. تعد زينـة/ زينب الثخصـية الرئيسـة التي يدور حولهـا المحكي

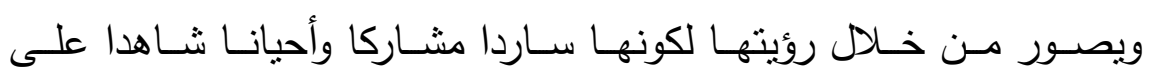

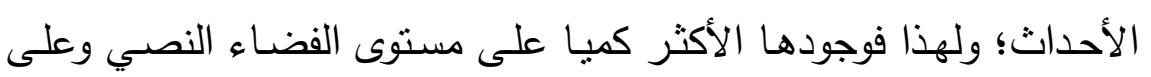

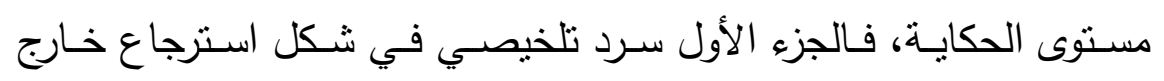

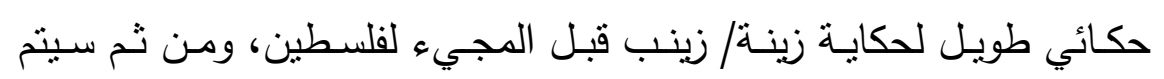
التركيز على برنامجها السردي وما يحتويه من تثاكلات.

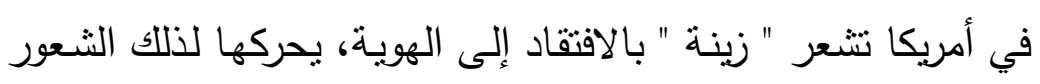

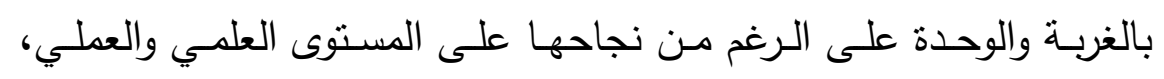

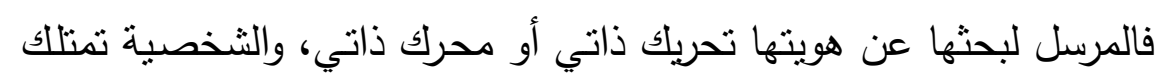

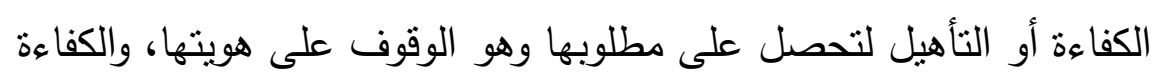

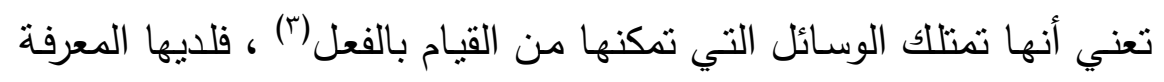

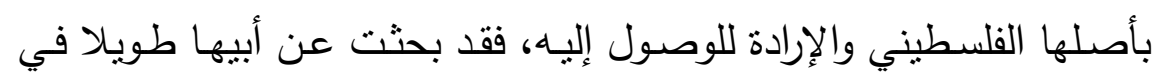

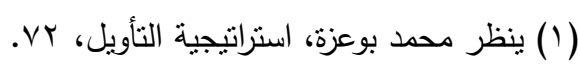

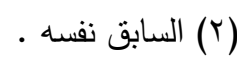

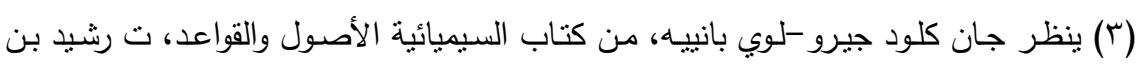

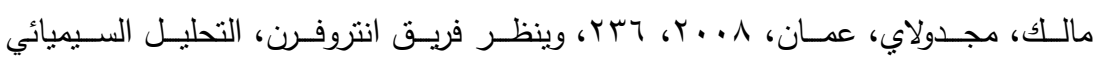

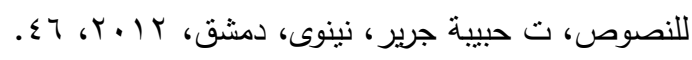


أمساكن نشـأتها بعـد أن هربـت منـه، ولـديها القدرة فترى الذهاب لفلسطين ضرورة، كما أنها تمنلك المال لتفعل، ما يمنل نشاكلا دلاليا يرد في سياقات متعددة، ثقول في مناجاة عن محركها الذاتي والافتقاد للهوية:" وكانت "نحن" تؤلمني، فما نحن؟و من نحن؟ نحن الأمريكان؟ أنا لست أمريكية. " من أنت إذن؟ "سألتتي يوما حين كررت ذلك القول.لم أقل عربية لأنني لست كذللك؟ من أنا إذن؟ بالرغم من جنسية أمي، شهادة ميلادي، شهادة مدرستي، كتبي،

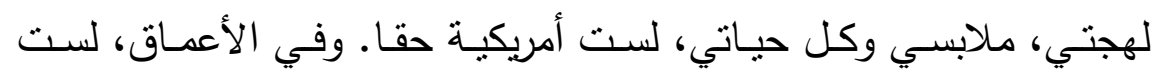
أمريكية حقا. تلك الأعماق المسكونة برؤى وصور ، بمواويل شوق تلوح كنفح النسيم، عبير البنفسج، شذى الذكريات، وتترك في القلب ذوب عسل، تهب

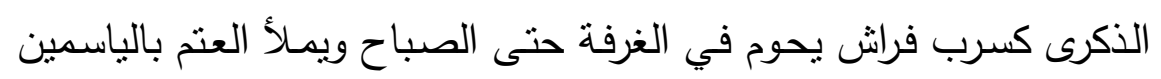
وطيب البخول ونكهة قهوة وهال ولوز وقرفة ومحلب وجوزة الطيب وخبز

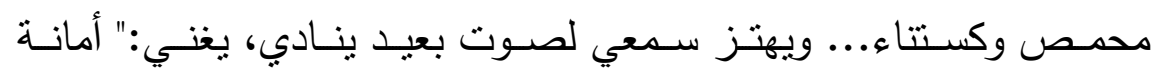

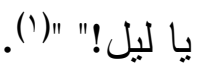
وعن الإحسـاس بالوحشـة النـاتج عن افتقـاد الهويـة تقول: "حياتي الأكاديمية كانت قفرا بدون طعم أو إحساس... مـع الأيـام، صـارت الفجوة أوسع حتى تعبت من الوحشَة وبت أحن إلى الماضي بدون لف أو دوران.

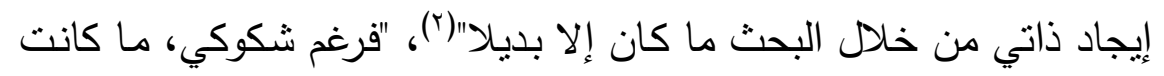

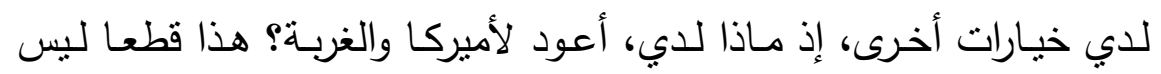

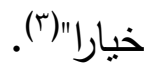

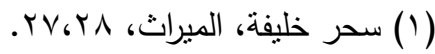

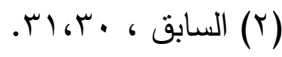

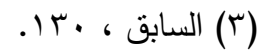


ثم عادت لفلسطين فأصبحت على شفا تحقيق فعلها، وعلى الرغم من

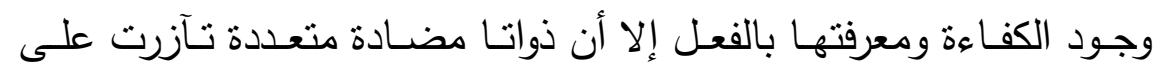

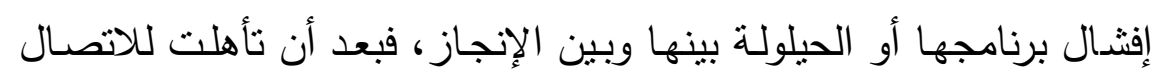

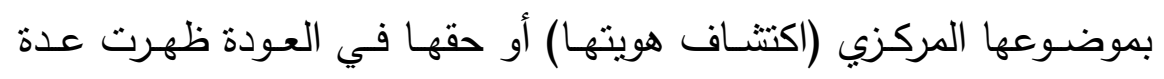

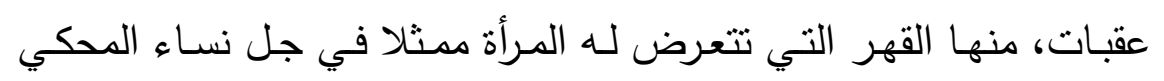

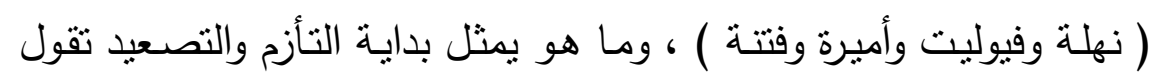

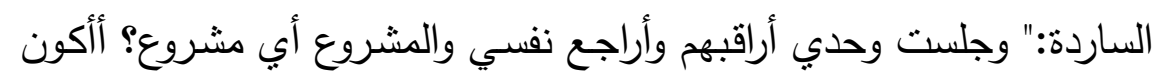

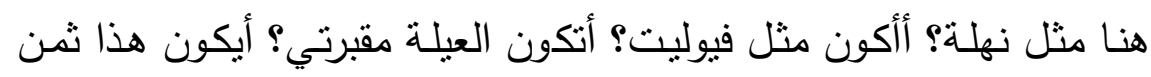

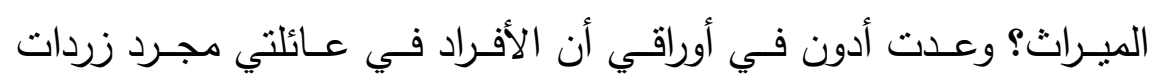
مفروطة في سلسلة أصدأها القهر"( (1).

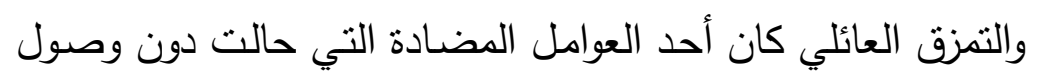

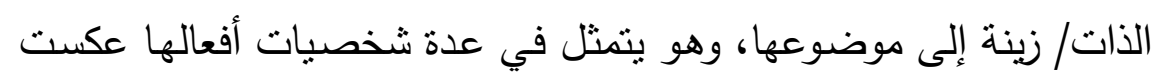

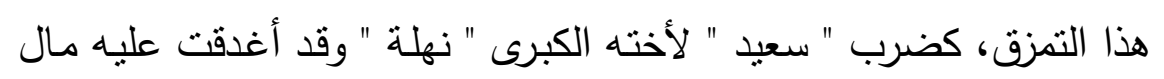

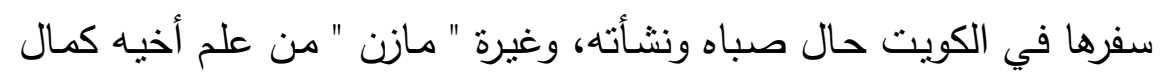

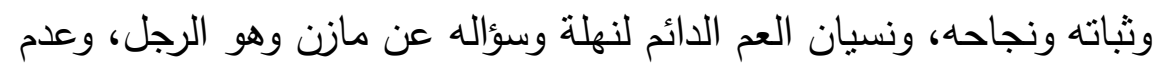

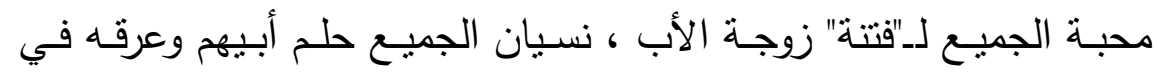

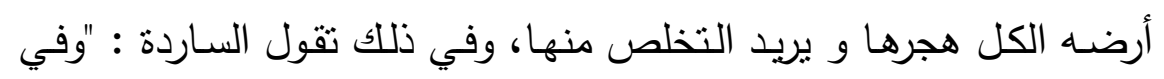

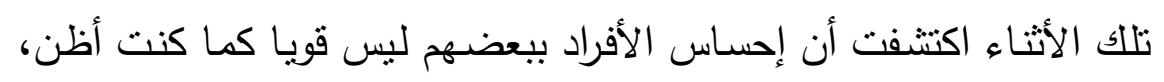

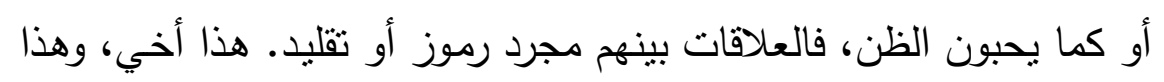

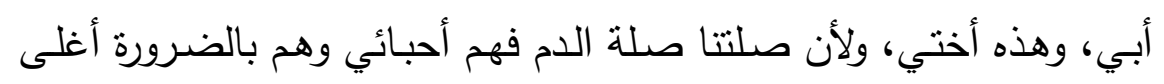


الناس. أما التطبيق، أما الواقع، فكل يعيش في فلكه وله دنياه"(')

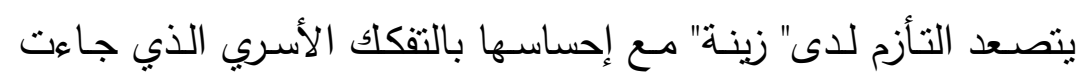
تبحث عن ضده، وذلك التأزم يحصل ليمهد لانفصال زينة" عن موضوعها؛

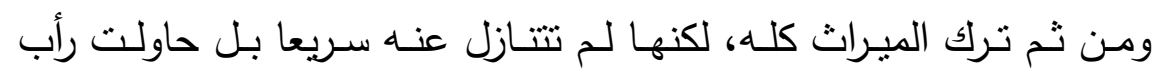

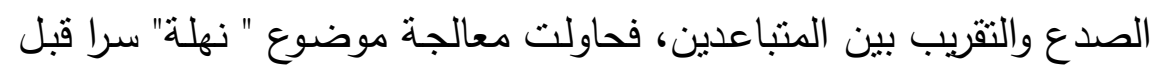

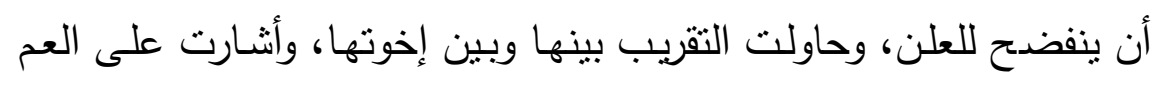

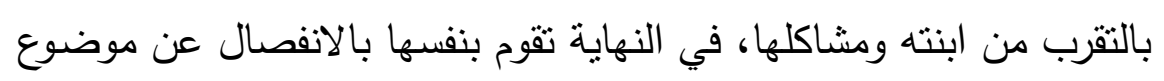
قيمتها، وهو ما يسمي بالتتازل (؟).

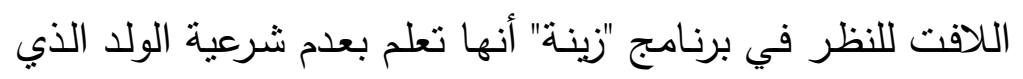

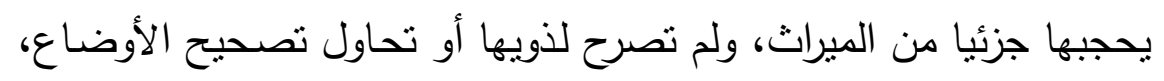

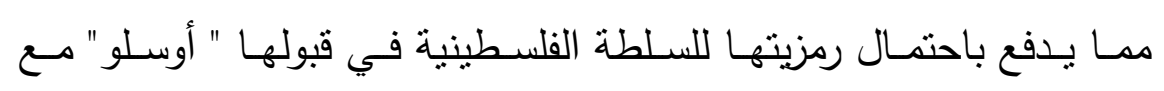
المعرفة بعوارها وكارثيتها.

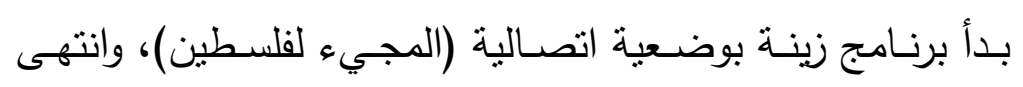

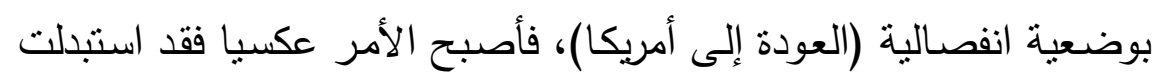

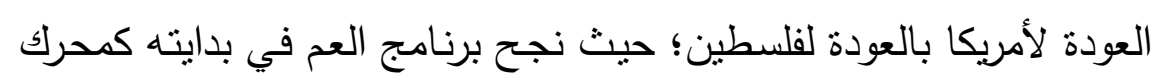

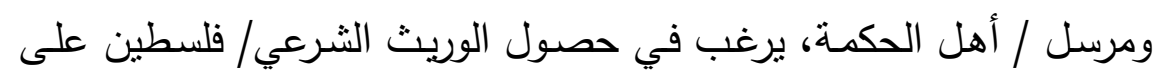

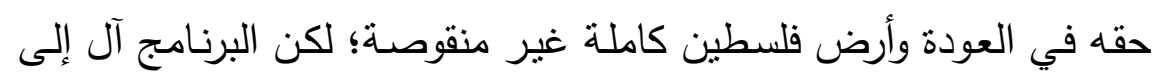
الانفصال باختيار الثخصية العودة لأمريكا وترك الميراث كله معلقا.

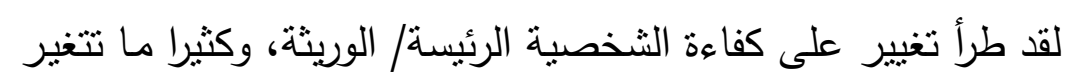

(1) (1) سحر خليفة، الميراث، .17)

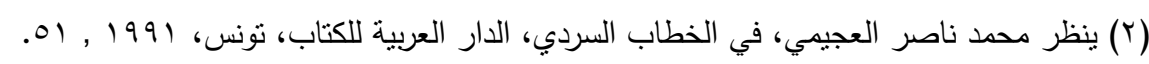


الكفاءة في الخطاب (')، فكلما توغلت الثخصية في مجتمع ما بعد "أوسلو" كلما قلت كفاءتها، ما يعكس المراد بثه في تدهور الأوضاع بعد "أوسلو". وشخصية "كمال" ترغب في رفع مستوى بلده فلسطين بالعلم وتتمية

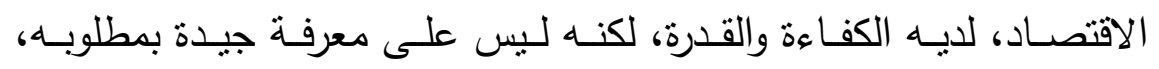
فتواجهه عدة عناصر مضادة ممثلة في : فساد البلدية (الرشوة والمحسوبية) يقول الراوي: "ووجد كمال بن أبي جابر نفسه يتخبط في معركة لا يفههها. إذ لم يفهم سر التأخير في صدور

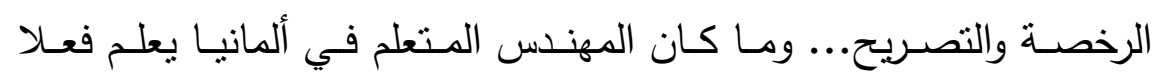
بأصول الثغل. فالثغل هنا شيء آخر ...ومنطق الكتبة والمسئولين وضباط الأمن والمستأمن وحامي حمى الخط الأخضر ثم الأحمر ثم لون الدم، أبي

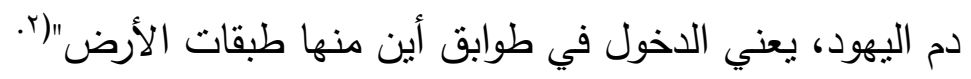

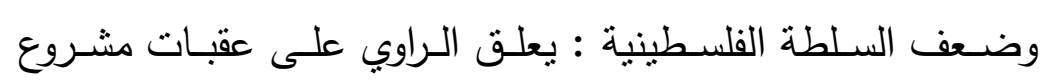
كمال: "الماء طبعا ملك عام، للبلدية، وكذلك للسلطة بشقيها، سلطة الحكم،

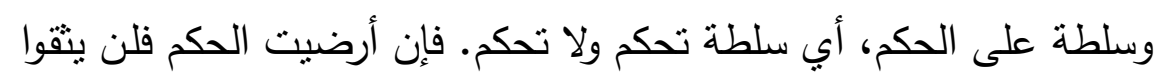

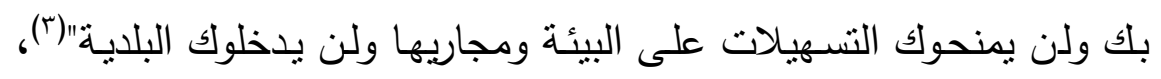

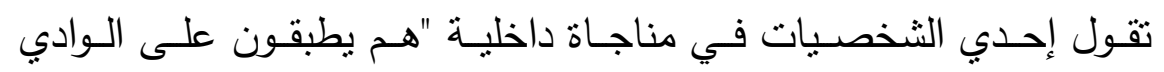
(الإسـرائليين) ويعتلون الجبال ويتمترسون في المرتفعات كما فعلوا بجبال القدس. القدس حاطوهـا وخنقوها، ثم ابتلعوها وانتهى الأمر ، وجبال الضفة

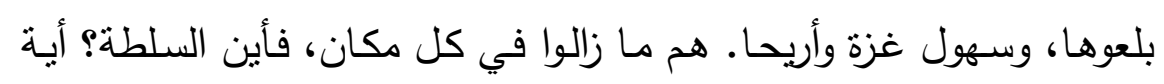

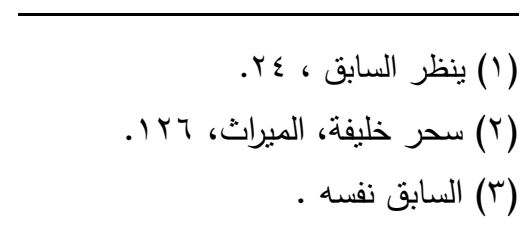


سلطة؟ أبدون السلطة يكون وطن" (').

والتمزق الأسري وصراع العائلات : الذي يمثل المال سببه الرئيس

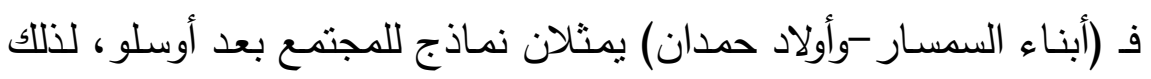

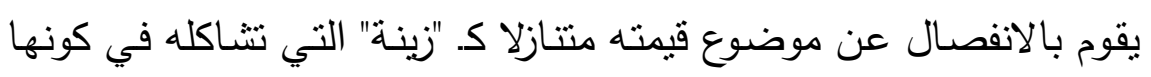
من منقفي عرب الثتات.

و تردي الأوضاع السياسية والاقتصادية : " فلم تجد السلطة مخرجا

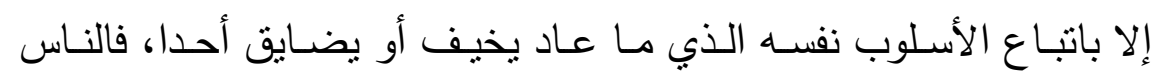

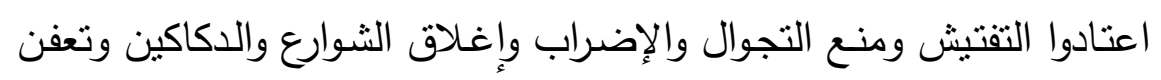

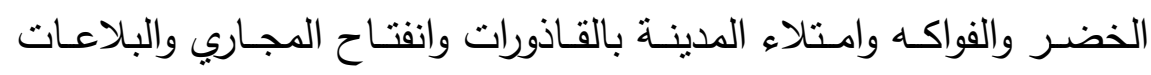

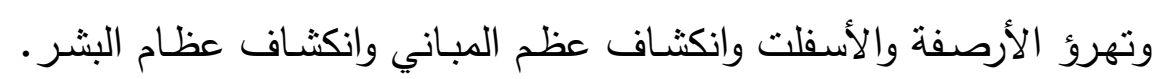
اعتاد الناس القلة، واعتادوا الدذلة..." (؟).

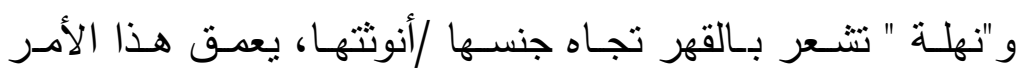

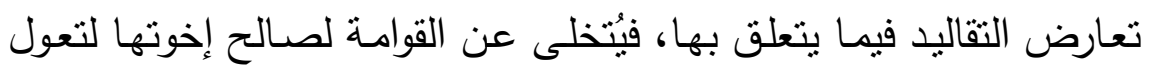

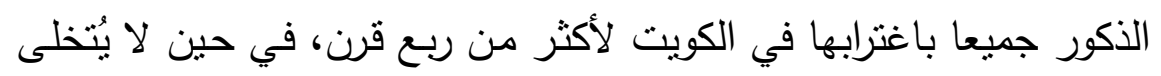

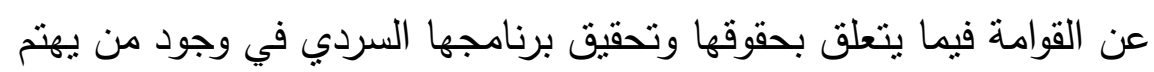

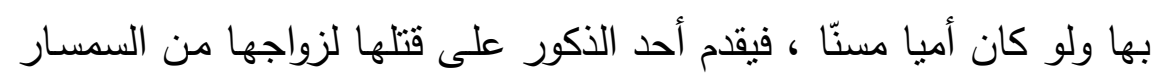

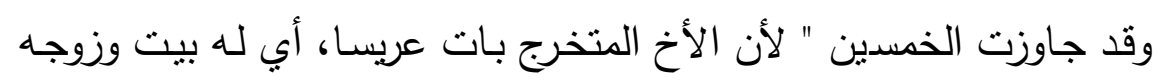

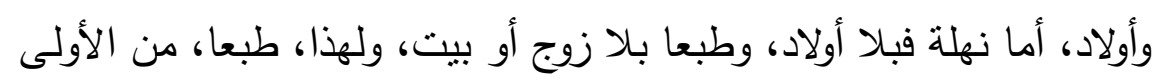

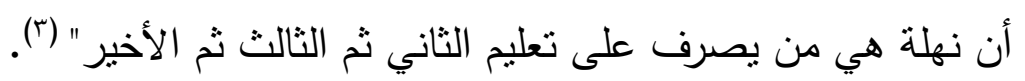

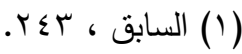

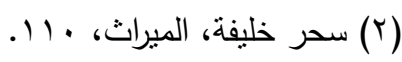

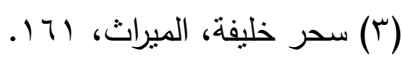


و "عبد الهـادي الثـايب" سـليل عائلــة ذات حسـب وتـاريخ سياسـي

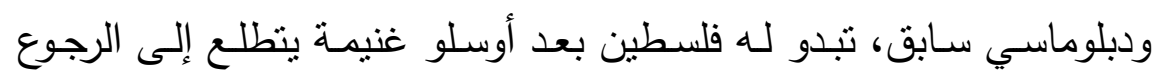

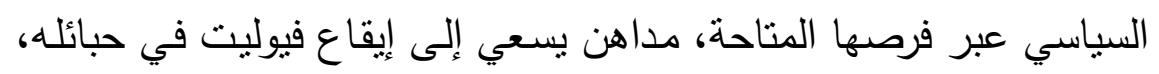

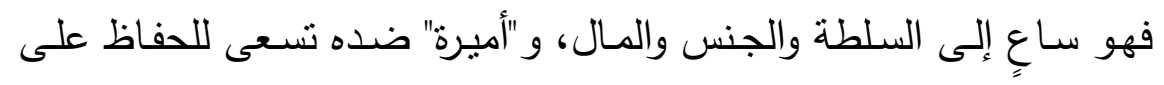

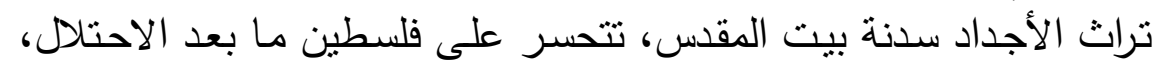

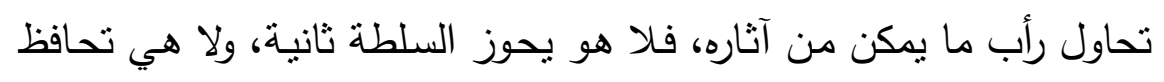
على الميراث بل تضطر لتنربية طفل التلقيح اليهودي.

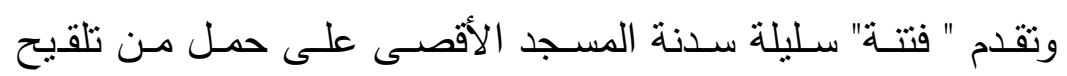

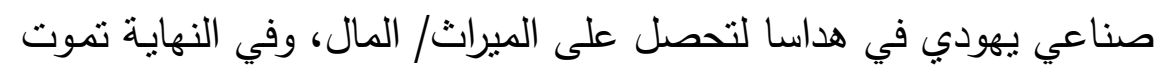

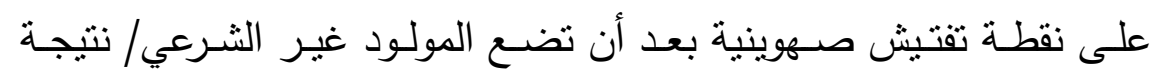

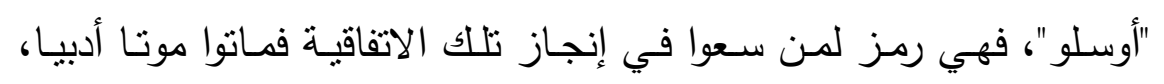

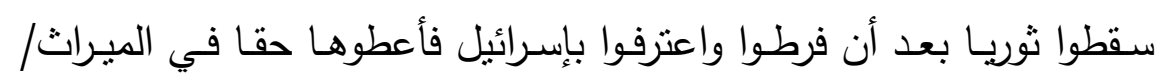
فلسطين. بـات واضــا مـن البرامج أن عدم الوحدة والتمزق الأسـري وسـوء

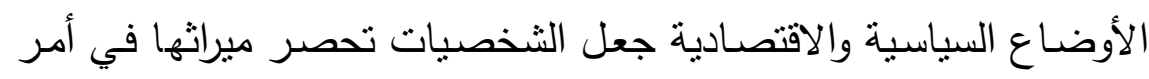

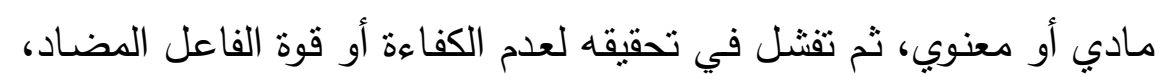

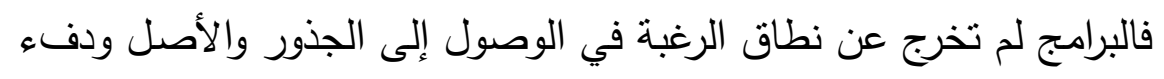

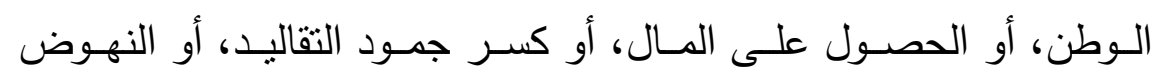

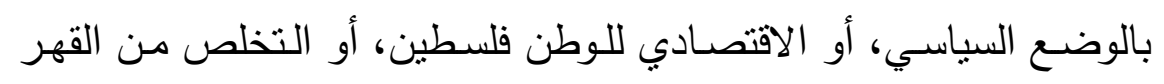

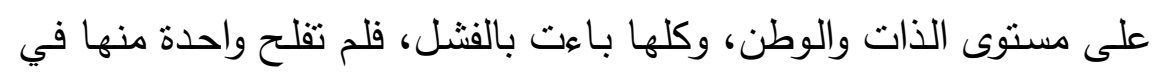

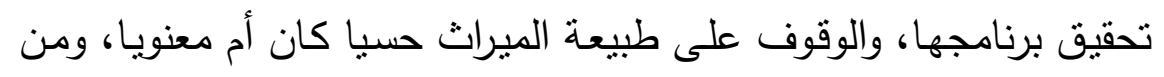

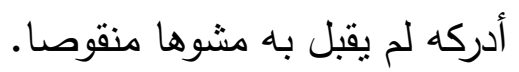


وهناللك عدة تتاقضـات مضمونية تتـكل بنيـة الحكايـة العميقة التي كي

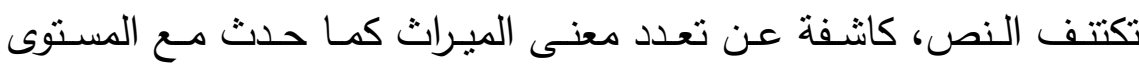
السطحي، فبينما كان التلاحم الأسري ظاهرا كان التفكلك والتمزق باطنا, وفي حين رأينا الحرص على النضـال السياسي في السطح لبعض الثخدي الثريات

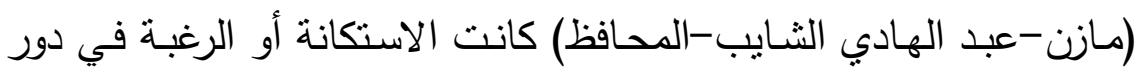

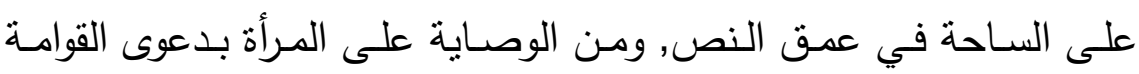

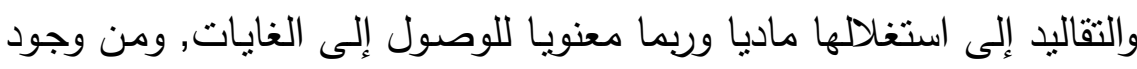

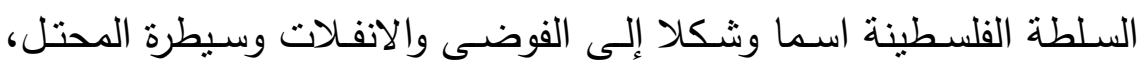
ومن نبرة وطنية خافته ترد في المنولوجات الداخلية إلى الفساد الإداري في السلطة. 
العنوان والمكان

يتفاعـل المكـان مـع العنـوان بقوة؛ ذلك أن اسـتهلال النص بـادئ

بالتحديد المكاني، وكذا النهايـة مـع اتحـاد الفاعل في الموقعين (استههل النص-خاتمته)، وهما عتبة من عتباته الضاربة بجذورها في الأهمية، ومن وهن هنا تكون دراسة تفاعل العنوان مع عنصر المكان أمر يحقق نتيجة فاعلة. يستهل النص بمجيء الراويـة/زينـة إلى الضـفة بفلسطين ويختم برحيلها عنها، وبين الحدثين تتباين وتتتـعب الأحداث، لكنها تقدم عبر لران المقارنة بين الوطن والمهجر طبيعة المكان وعلاقته بالعنوان. فإذا كان الميراث هو المـال أو الحسب أو كل مـا يمكن أن يورث وينتقل من الأسلاف إلى خلفهم، والميراث كموضوع أو مرجع يتطلب وارثاً ومورثاً وعينا موروثنة، والوارث والمـورث سيتطرق إليهما في الثخصديات، أما الموروث فهو في شقه الحسي المال المتروك "(هذا ما قاله عمى لي في الرسـالة) وقـال مـا معنــاه الحقي حالــك وخـدي الميـراث، إذن فهـذا هـو الميراث" (')، وترد كلمـة ميراث في أكثر من موضـع تحمل دلالـة (المـال، الأرض الكائنة للفتاة في فلسطين)، وبتأمل السياق نجد تكرار كلمـة ميراث

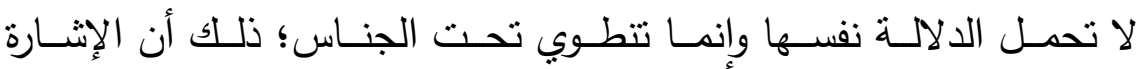
المصاحبة للجملة الثانية تومئ إلى مرض الأب الثديد ووجود زوجة شـابة

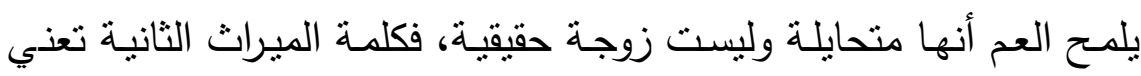
رغبـة الأسرة في الاحتفاظ بمال الأب دون الثخصية الاخيلة، فالرغبة في البحث عن الهوية تلوث أمام الثخصية بنوازع المادية ليبدو أن الميراث هو الاهي 
المكان/ فلسطين، أو النوازع الماديـة، وبهذا صـار المكان فلسطين حاضرا بـالقوة في العنوان كمـا هو حاضـر في النص، وقد بـدأت بـه الروايـة وبـه ختمت مـع تغاير الحدث، فهذا المكان قوة فاعلة في النص فسرت المفتئح

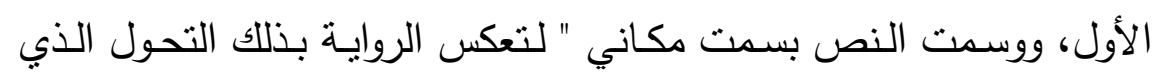
جرى في الاستراتيجية الكتابية في الرواية الحداثية من حيث اتخاذها للمكان قوة نصية بعد أن همش (المكان) من الإهمال واللاوعي بوظيفته البنائية والإنتاجية للمعنى في الفكر الروائي" (').

وفيما يلي سنعقد مقارنة تبين المفتتح والختام بتجلياتهما المكانية:

\begin{tabular}{|c|c|}
\hline 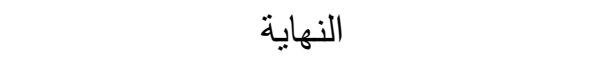 & البدايــة \\
\hline "أوصلني عمى إلى المطار وقال بعتاب: & "جئت إلى الضفة، بحثا عنه، بحثا عنهم، \\
\hline - معقول تروحي وتتركينـا؟ مســت دمـوعي & بحثا عن وجهي في الغربة، حتى أعرف ما \\
\hline لأول مــرة منـــــــــنوات، لأنـــي وجـــت & سـوف يكـون، وصـلتني رسـالة مـن رجـل \\
\hline إحساسي، وقلت بحنان: & يذكر منها أن الوالد في مكان مـا، أي أنـه \\
\hline - راجعة، راجعة، والله راجعة & حـي يـرزق، أن الرجـل هـو عـ لـي، وأن \\
\hline 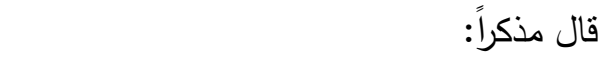 & المكان وادي الريحـان، فرق كبير ، مسـافة \\
\hline ـ وأخوك الصغير ، لمين نتركيه؟ & طويلــة، بــين نيويــورك وواشــطن، ووادي \\
\hline 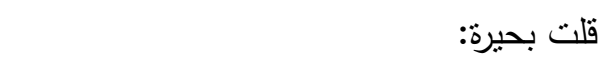 & الريحــان، وادي الريحــان كانــت أبـــاً فـي \\
\hline البركة فيك وفي أميرة. & ذاكرتي عكس نيويورك، بلدة صغيرة، بلدة \\
\hline 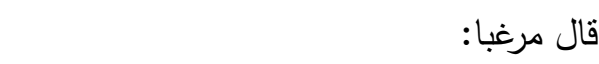 & نقية، أهلها بسطاء يحبون الخير والطبيعة، \\
\hline ـ صحيح للولد ضـف البنت، بس أنت كمـا & بعكس نيويورك" \\
\hline نصييك محفوظ. & \\
\hline ـ هـززت رأسـي بـدون تعليـق، ومشـيت نحـو. & \\
\hline 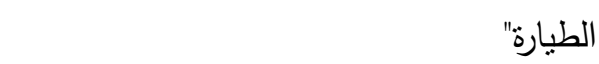 & \\
\hline
\end{tabular}

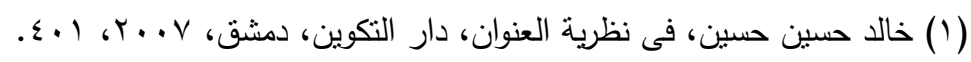


حددت البداية الفضـاء النصـي الذي دارت فيه أحداث الروايـة، ولم

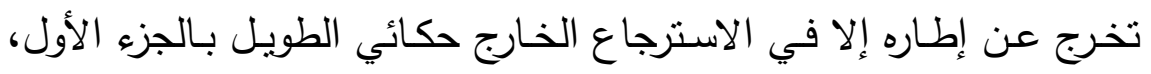

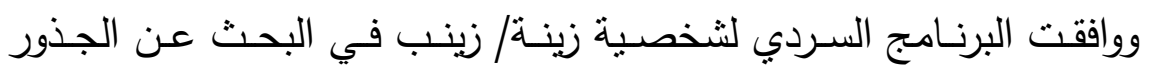

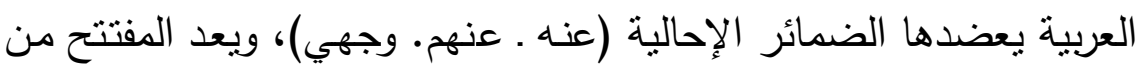

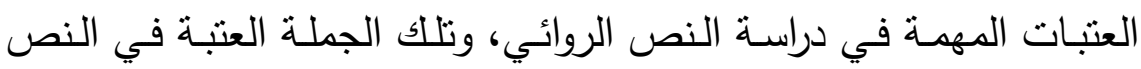
السردي تمثل حدا واصـلا بين الوجود والعدم، مدخل أو جسر العبور بين

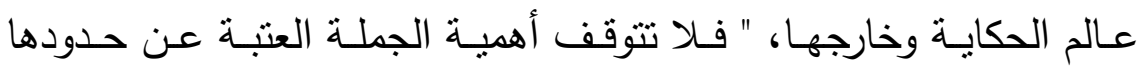
النحوية فقط، بل تطال وتتحكم في جميع ممرات النص، مـا دامت الدليل الذي تسبر وفق خطوطه العريضـة تشاكلات النص، والبداية التي ستضيئ كل عتماته"(')، فقد حوى المكان والثخصيات من وارثين وموروثين، كما لتهات حوى الميراث.

ويتكرر اسم "وادي الريحان" في " نابلس" مع الوصف الذي يقابلها بـ "أمريكا" مكانا وشعبا، أما النهاية فتمثل نهاية البرنامج السردي للشخصية لـانية بالفشـل، واستبدال القدوم إلى وادي الريحان/ البحث عن الميراث/ الجذور والأهل وحق العودة، إلىى الرحيل عنـه وترك الميراث كله؛ فبـأت الروايـة

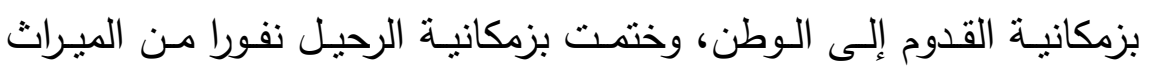
المعنوي، ويلاحظ في المفتتح تكرار مادة " بحث" الدالة على شيء مفقود، كان موجودا لكنه فقد بالنسبة إلى الجيل القديم، أو الدالة على شيء موجود لكنه لم يمتلك بعد للجيل الجديد، ما يساوق كلمة" تكتشف" في الإهداء.

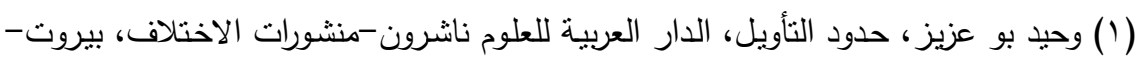

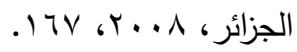


ولما كان الميراث في جانبه المادي المباشر ممثلا في أرض الأب بوادي الريحان فكان طبيعيا أن يتجلى وصف الوادي/ الميراث بالنص بأكثر من شكل، فورد الوصف تعبيريا مما جعله يخرج من إطار الواقعية الصرفة

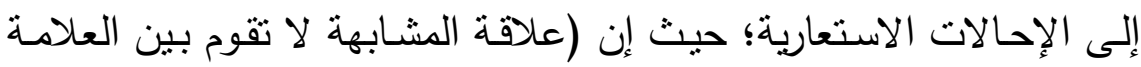

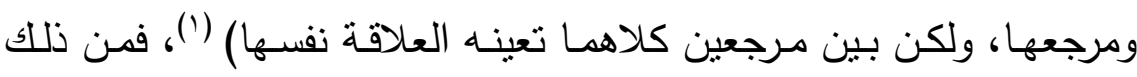
وصف الطريق المؤدي إلى بيت العم في "وادي الريحان": (حملت حقيتي ومشيت في طريق أسفلتي مهجور ضيق مليء بالحفر والتعاريج والنباتات

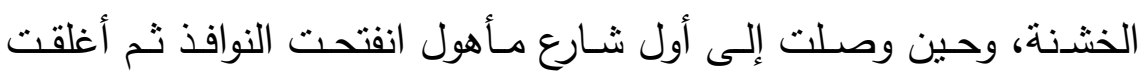
بسرعة، لكن الأيدي ظلت تمسك بالستائر تزيحها عن شقوق تمكن الوجوه

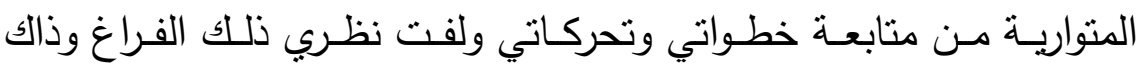
السكون، فـلا نـاس ولا سـيارات، ولا أولاد ولا مـارة، كل شـيء سـاكن جامــ

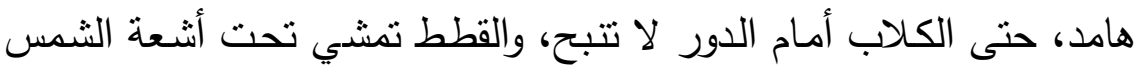
بـبطء وبـلادة، وروائَح الزبالـة والزبـل وعبيـر أثـجار الكينـا تشـكل مزيجـا

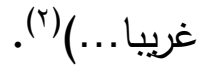

(1) أرت فان زويست من العلاماتية وعلم النص، منذر عياثي، هor.

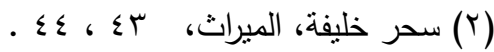


فالمشـابهة كائنـة في المرجـع المباشـر للعلامـة (وادي الريحـان)، والمرجع غير المباشر الحياة الاجتماعية والسياسية لأهل فلسطين إجمالاً،

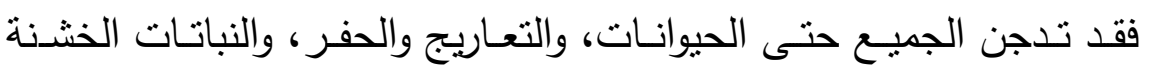
الحياة الاجتماعية وقد شوهتها تقاليد بالية، وتداخل الروائح الطيبة والكريهة

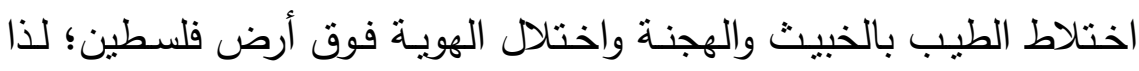

نجد الأطفال يرددون التحية الإسرائيلية للشخصية (شالون با مرة) ('). إن وصف المكان هـا هنا أضفى الصبغة العاملية على الفضـاء بتعبير (هنري ميتران) (r)، ففلسطين الوطن الذي تقصده الثخصية المغتربة هية هي مـادة الحدث، وتكاد تمثنل عـاملا ذا دور في النص؛ إذ يثنكل معيقا لأكثر من شخصية وخاصة المتقفين من فلسطينيي الشتات" زينة" و " كمال" لهال اللذين صدمهما الواقع الفلسطيني، وعلى رأسه المكان الذي شوهه الاحتلال والفساد الذي تصاعد بعد أوسلو، فكانت إعادة النظر في الميراث. وتتحول بعض أشياء المكان إلى رموز دالة تتصل بالعنوان بأوثق الصلات، فالرمز " ليس فقط عامـا باعتباره علامة، فهو يحيل إلى موضوع عام لله وجوده في الحالات الخاصة التي يحددها والتي هي حالات موجودة

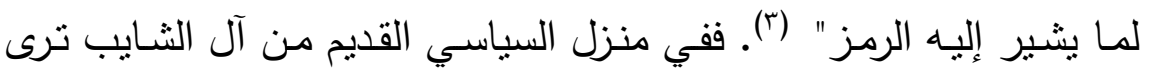

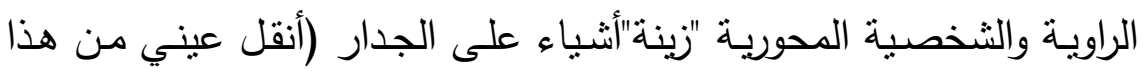

( (1) سحر خليفة، الديراث، ؟ ؛. (r) ينظر هنري ميتران من الفضاء الروائي، ت عبد الرحيم جزل، إفريقيا الثرق، الدار البيضـاء، . 109 ، r...

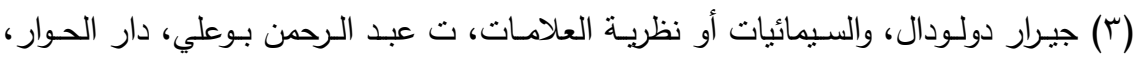

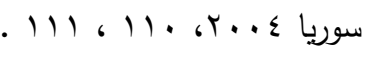


إلى ذاك وفي الديوان وأعلى الجدار ورأس الغزال وبوستر الأقصى فوق رأس

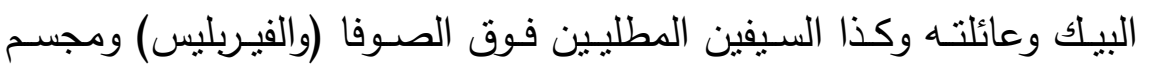

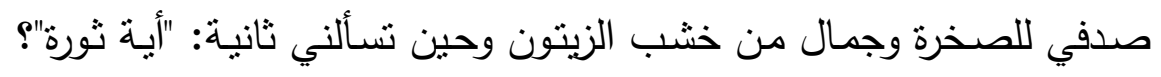

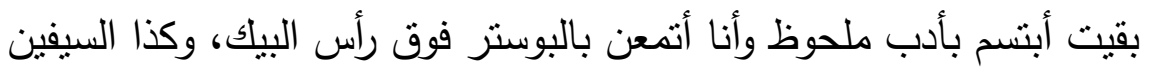

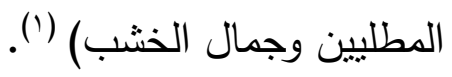

النأويل يحيل على المعنى وهو مرتبط بالأيديولوجي، وتعد اللوحات

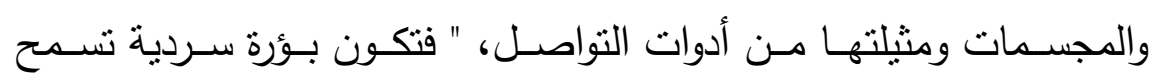

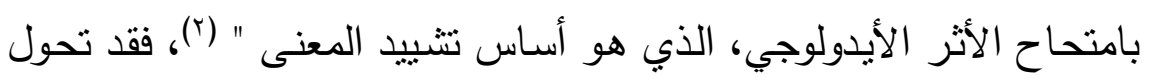

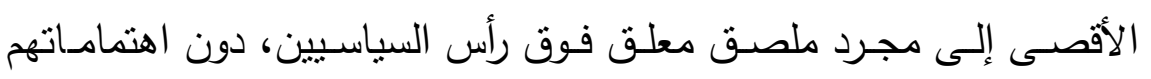

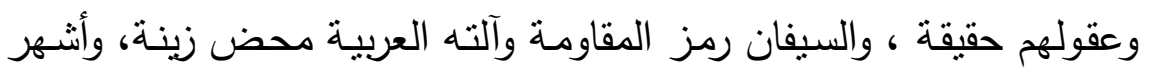

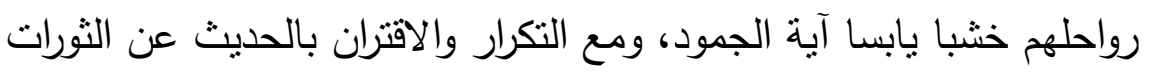

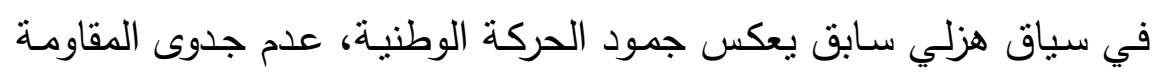

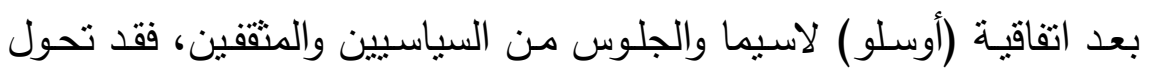

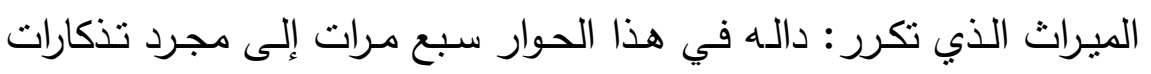

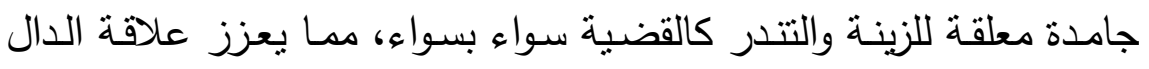

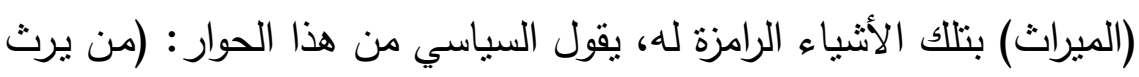

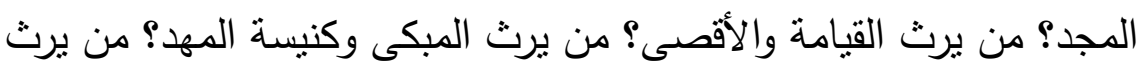

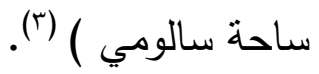

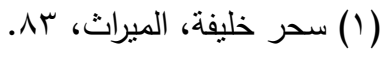

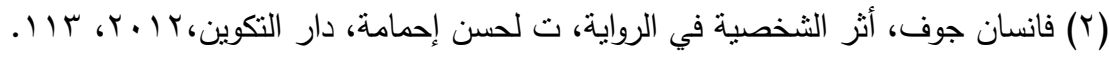

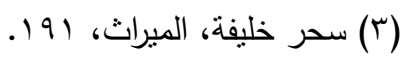


ويعد فساد مشروع تحويل مياه النضح إلى سماد وماء صالح للشرب

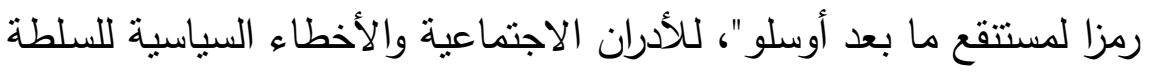

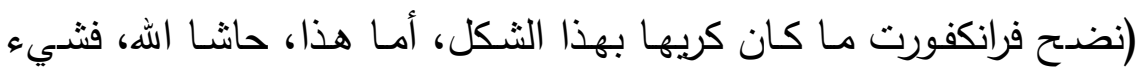
مرعب شيء قاتل...وما الفائدة من عمل وليس لديك أساس الحياة، مرت هرت

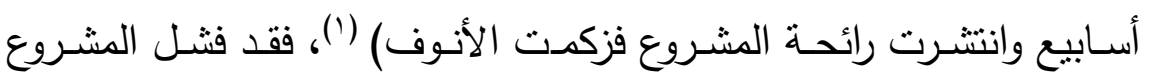
لرغبـة البعض في الاسـتئنار بـهـ وإقصـاء صـاحب الخبـرة العمليـة والعلـم

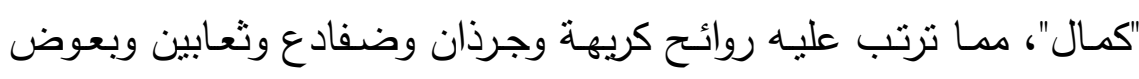

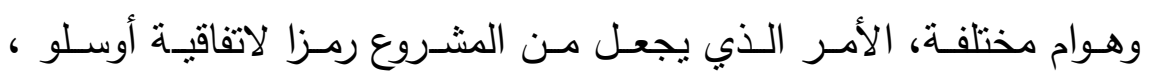
فالميراث/ فلسطين تقاسمه القائمون عليه حتى باء بالفشل و ( انقسم الجمع

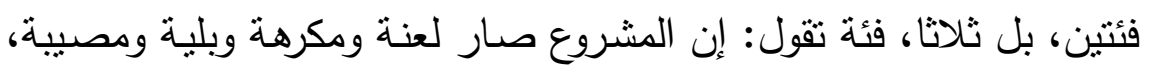
والفئة الأخرى تقول: إن المشـروع إنجاز عظيم لأنسه يحمي البيئة وينقيها

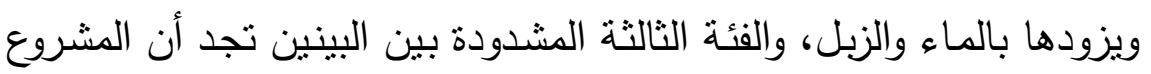

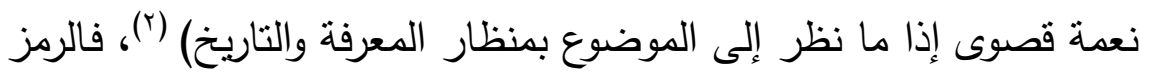
المكاني هنا عمد إلى "تحويل حقائق أو أحكام مجردة إلى كيانات مجسدة إنى إنى من خلال أثنياء أو سلوكيات محسوسة" (r).

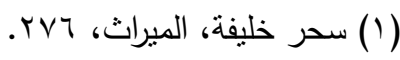

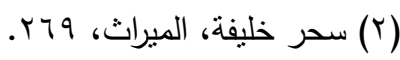

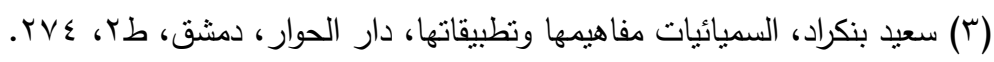


الثخصسيات رمـوز أو نمـاذج لأنمـاط اجتماعيـة تحيـا في المكـان المرجع /فلسطين، بدأ ظهور الثخصيات في المفتتح في شكل ثنائية الوارث

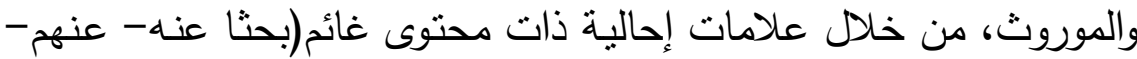

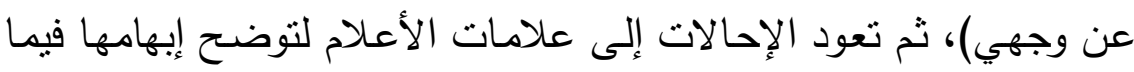
بعد، وقد اكتفي في الثخصيات على المواصفات المعنوية دون الجسدية، ما يؤكد أن الكاتب الضمني يقدم نماذج وأنماط بشرية، وليس كائنات مرجعية مخصوصة؛ لذا لم ترد شخصية مرجعية تاريخية واحدة على الرغم من زخم

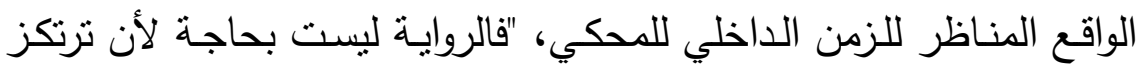

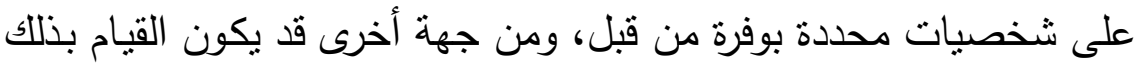

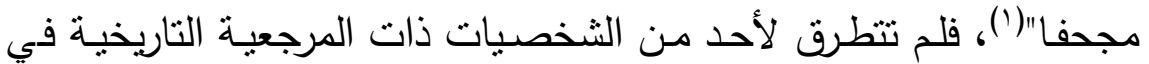
الواقع الفلسطيني، لكي لا تضطر إلى منحها سمات قد تنتاقض حقيقتها أو لأون

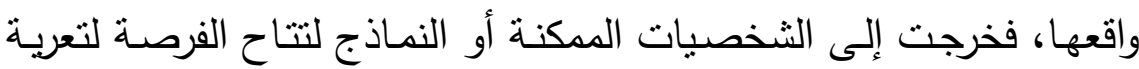
الواقع دونما حرج.

زينة / زينب هي الثخصية المحورية التي تضطلع بالحكي، ويعد دالها

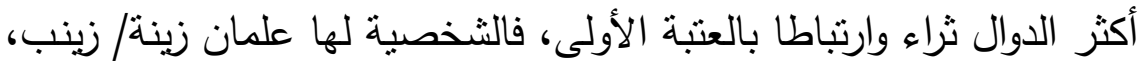
الأول غربي والآخر عربي خالص، مما يتتاسب ووظيفة الثخصية وطبيعة برنامجها السردي في التوزع بين هويتين لا تقر على إحداهما، بينما تظل

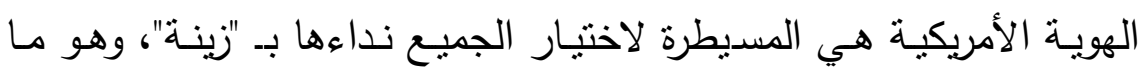

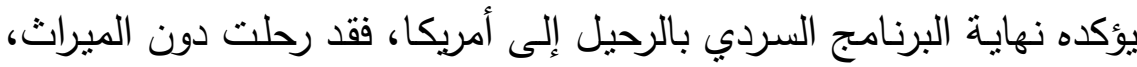

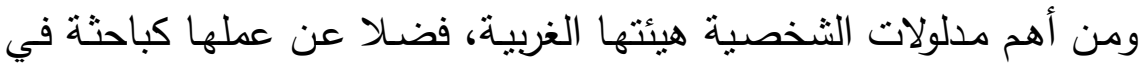


علم الإناسة الذي مكنها من الوقوف على طبيعة الميراث المعروض عليها

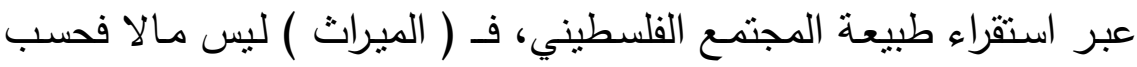
وإنما هو الهوية وما يحفها من عادات وتقاليد يتقيد بها الوارث مادام الميراث كائنا بأرض فلسطين، ومخزون ثقافي وأدبي، وأسدلوب ونمط حياة، ويأتي رحيلها رمزا لإقصاء فلسطيني الثتات بسبب "أوسلو".

و (كمال) المهذدس المغترب بات واضحا من النص ودوره الوظيفي أن

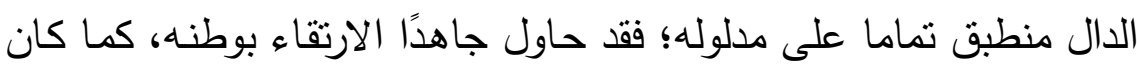

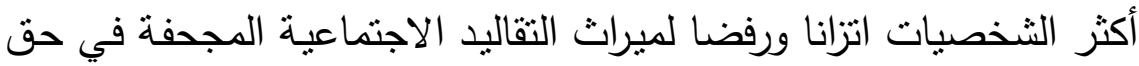

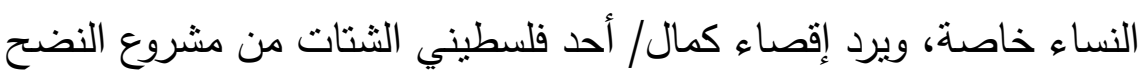

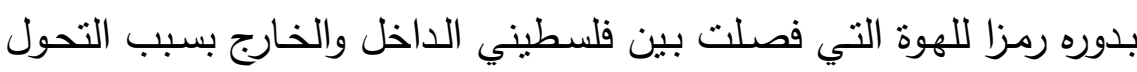
بعد "أوسلو" مـن الانضـواء تحت منظمـة التحربر الفلسطينية إلى السلطة المسيطرة-وفوقها سلطة-على الكائنين بفلسطين فقط. ويأتي الولد غير الثرعي لـ فتتة" نتاج التلقيح في هداسـا، والذي يحرم زينة/ فلسطين من ميراثها/ الحق الفلسطيني أو الهوية حجب نقصان، رمزا

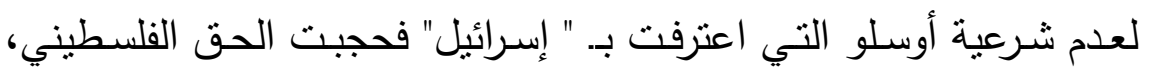
وغيرت الهويـة، ولعل معرفـة زينـة بهويـة هذا الطفل وسكوتها بـروه رمـز لمعرفة السلطة المسبقة بعوار الاتفاقية.

و (مازن جيفار) الدلالة اللغوية للاسم مع اللقب تشير إلى التتاقض، وهو حقيقة بادية في الخطاب، فكان في عنان السماء وقت النضال الماضي بلبنـان، ثم تضـاءل منصـاغرا في آنيـة الحكي مـع الاضطراب السياسـي،

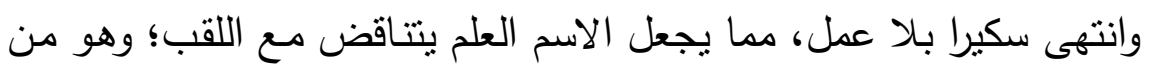
ثم يتوافق مع تقريطه في الميراث. 
والسمسار "أبو سالم "غلب اللقب عليه وعلى أبنائه، ففي كل يسيطر

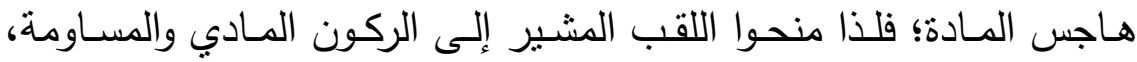

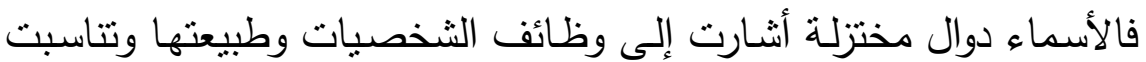
مع برامجها السردية؛ ومن ثم أفصحت عن مدلولات متعددة للعنوان المخاتل

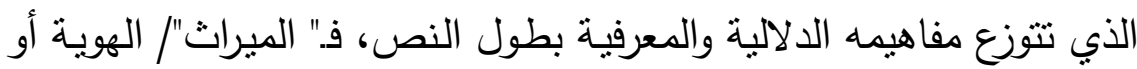
القضية الفلسطينية أو حق العودة تعثر تحقيقه بسبب أطماع مادية.

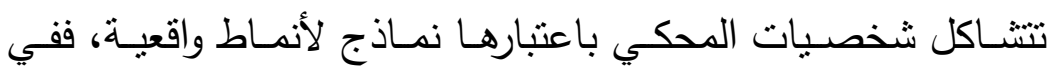

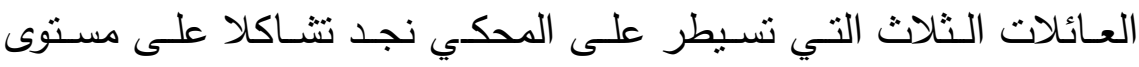

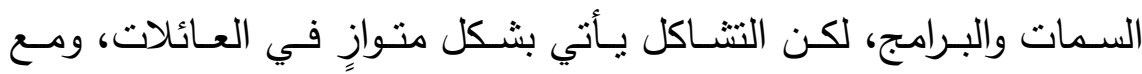

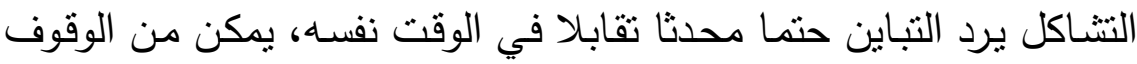

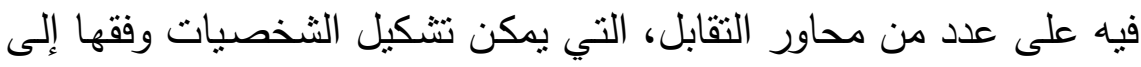

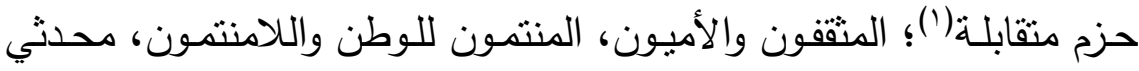

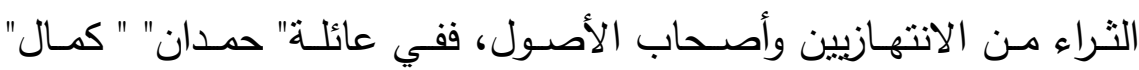
المغترب والمتعلم بألمانيا و "زينة "المغتربة بأمريكا باحثة الأنثروبولوجي، وفي الأني

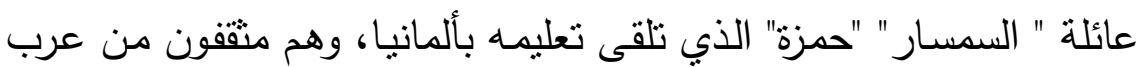

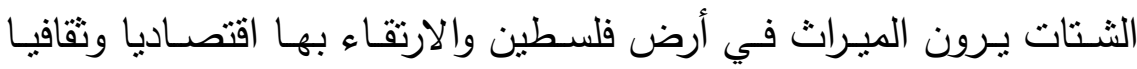

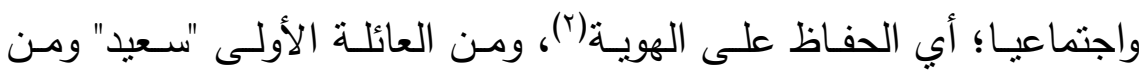

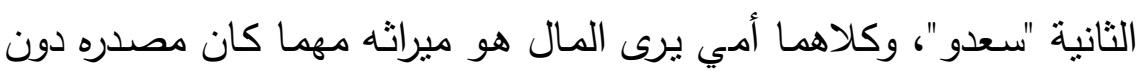

(1) ينظر فليب هامون، من أجل نظام سيميائي للثخصية من كتاب شعرية المسرود، الهيئة

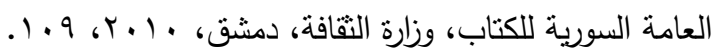

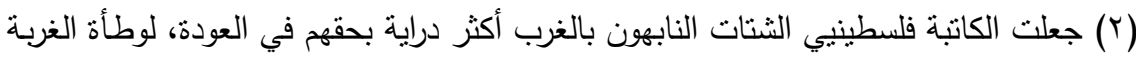

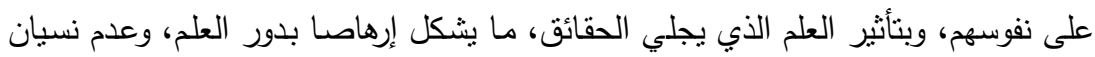
فلسطينيي الثنتات خاصة لحقهم في العودة. 
الأرض والقضية، وتعد " أميرة الثـايب" والعم عميد "آل حمدان" فريقا ثالثا

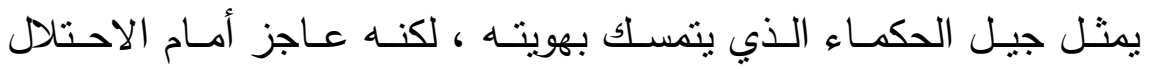

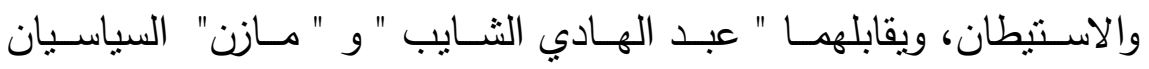
المفرطسان ، وأثزيـاء نـابلس والثـايب-حمـدان) قبـل أوسـلو وحديثي العهـد

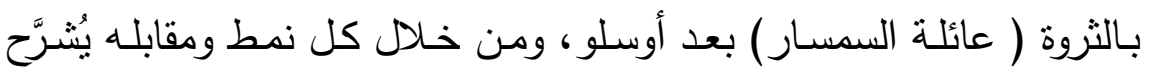

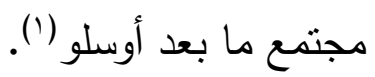
السارد صوت أنثوي بضمير "الأنا"، حضوره على هذا النحو معادل لتغييب المرأة في واقع الحياة، تحاول الاستعلاء على تهشيها خاصـة فيما

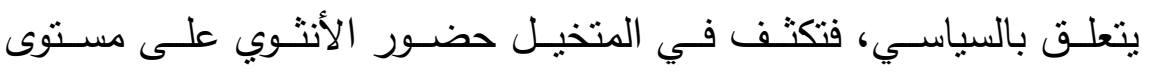

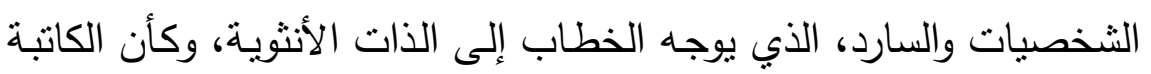
ارتأت أن تتقل مشكلة الهويـة وحق العودة بعيون ووعي أنثوي، فـالتبئير

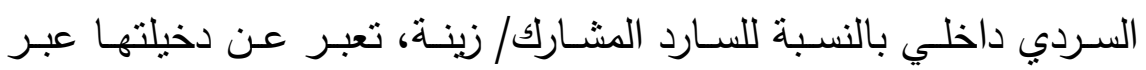

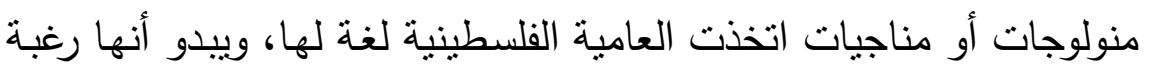
أكيدة في تمكين الهوية الفلسطينية بكل ما فيها حتى اللغة الدارجة، والهوية قضية الكينونة المصيرية للعرب إجمالا وفلسطين خصوصا. وفيمـا يخـص الثخصـيات الأخـرى منحـت الكاتبــة السـارد/ زينــة ابتـداء-بمسـوغ مهنتها كباحثنة في علـم الإناسـة-صـك التوغل في ذوات الآخرين، والتتقيب عما يحبط بالميراث من أدران حاقت بالذوات المقهورة،

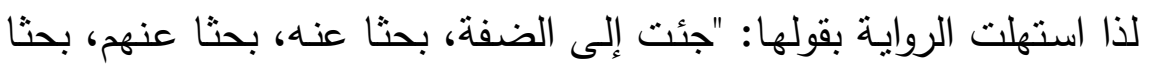

( ) ظهرت بعد أوسلو شرائح اجتماعية جديدة، ملكت الثروة ثم السبطرة والنفوذ طبقا لما أتاحته بنود أوسلو التي رضخوا لها، فأصبح هنالك ما بعرف بفريق أوسلو . 
عني وجهي في الغربـة، حتى أعرف ما سوف يكون"(")، فالكاتبة حريصـة

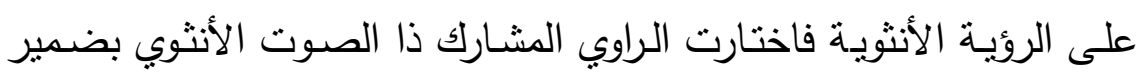

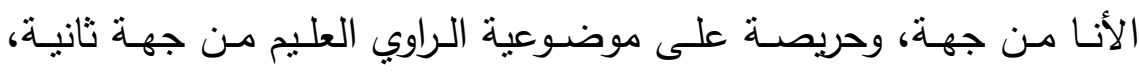

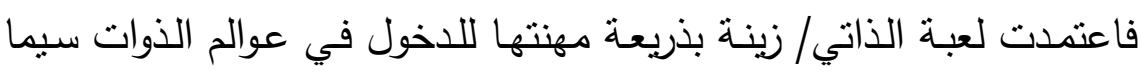
الأنتوية، تحفر في ثناياها بصيغة أقرب للسرد الموضوعي يغيب فيه صوت بـاته

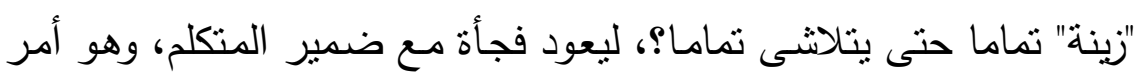
يحدث بالتتاوب سوى الجزء الأول المحكي بضمير المتكلم لكونه استرجاعا لحياة السارد في المهجر كقول الراوي: ( انتشرت ظاهرة المشاريع، فالجميع

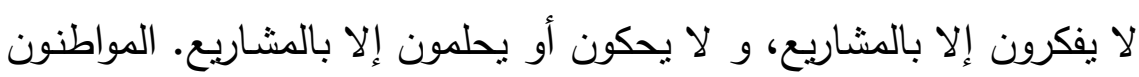

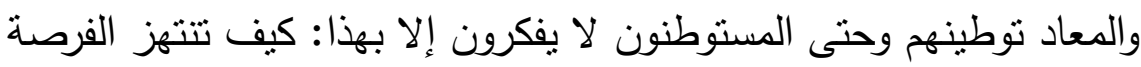

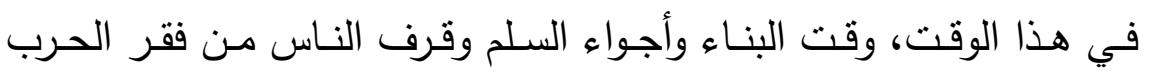
والانتفاضـة وتكسير العظام، وتقيم مشروعا مضمون الربح-والربح السريع؟ الـربح السـريع هـو المسـألة، فالكـل سـريع ومسـتعجل.... ثـ فاجـأني مـازن بمشروع جديد. قال المشروع هنا يبدأ-وأثنار لرأسـه. العقل جوهرة الانسان.

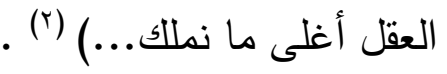

(1) سحر خليفة، الميراث، 1).

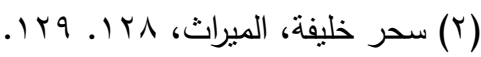




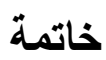

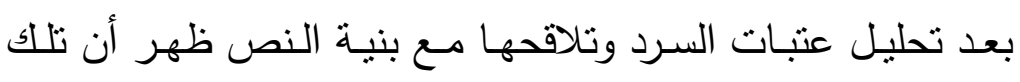

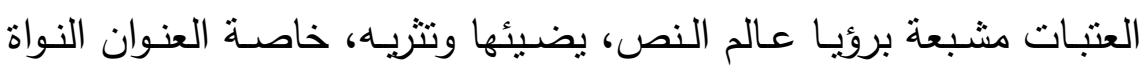

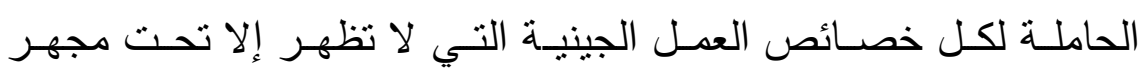

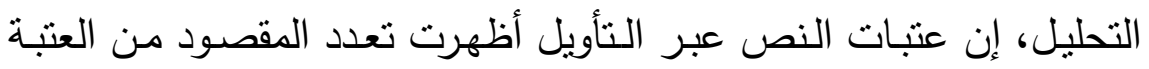

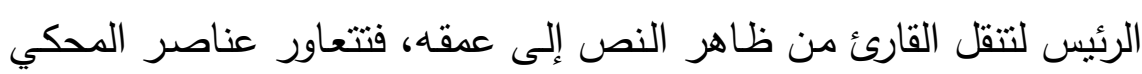

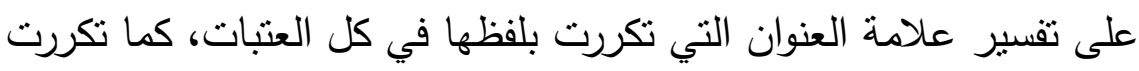
بطول النص حاملة أكثر من معنى، فكانت مقاربة لفئ بنية الحكاية والخطاب

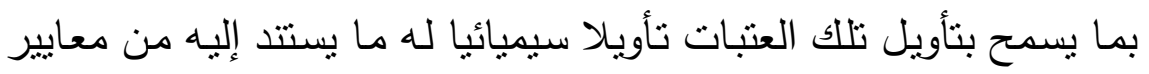

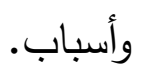




\section{المصادر والمراجع}

المصادر والمراجع العربية: (1) المدار

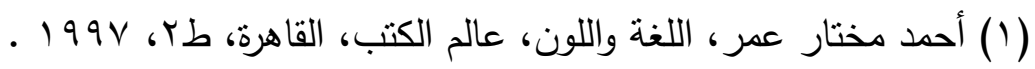

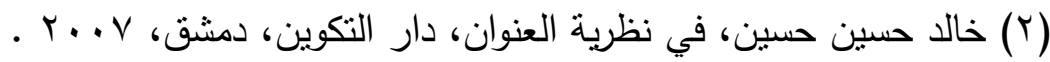

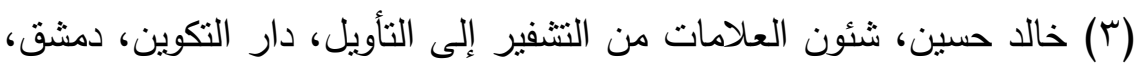

$$
\text { . r... }
$$

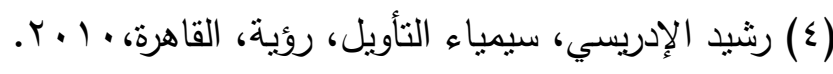

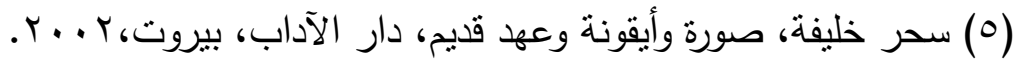

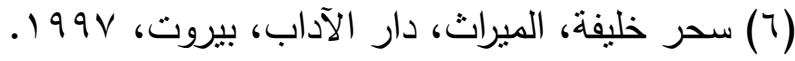

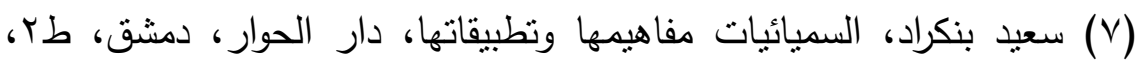

$$
\text { .r. . . O }
$$

(^) سعيد بنكراد، سيرورات التأويل، معالم نقدية، الأمان-الاختلاف-العربية

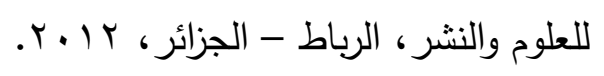

(و) سعيد يقطين، انفتاح النص الروائي، المركز النقافي العربي، الدار البيضاء،

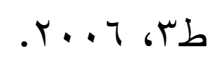

( ( (1) سوسن ناجي، المرأة الدصرية والثورة، المجلس الأعلى للثقافة، القاهرة، .r..r

(1') سيد محمد قطب وآخرون، في أدب المرأة، الثركة المصرية لونجمان،

$$
\text { .r... }
$$

(r (Y) طه وادي، صورة المرأة في الرواية العربية المعاصرة، دار المعارف، القاهرة، طع، ع 199.

(r/T) عبد الحق بلعابد، عتبات جيرار جينت من النص إلى المناص، منشورات

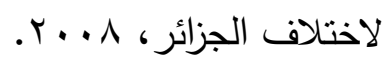


(ع () عبد الفتاح الحجمري، عتبات النص البنية، الرابطة، الدار البيضاء، .1997

(10) عبد المالك أنثهبون، في عتبات الكتابة في الرواية العربية، دار الحوار،

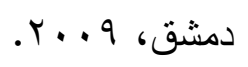

(7 1 ) علي الثدوي، المدار في الحكاية، النادي الأدبي بالرياض-المركز التقافي

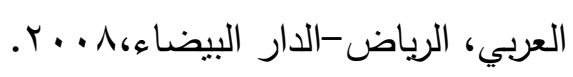

(IV)

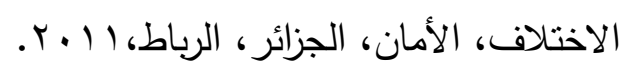

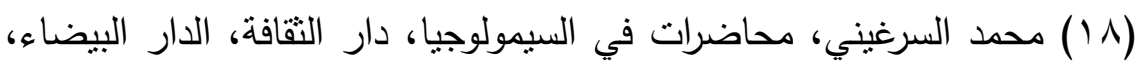

$$
.19 \mathrm{NV}
$$

(9 (1) محمد عبد المطلب، بلاغة السرد النسوي، الهيئة العامة لقصور التقافة،

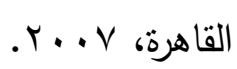

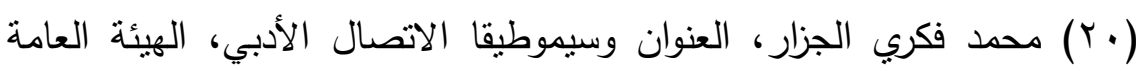

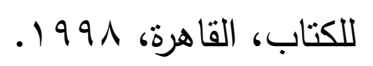

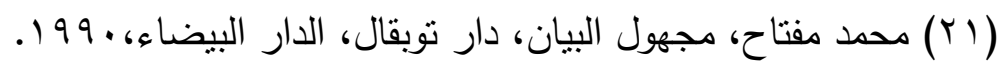

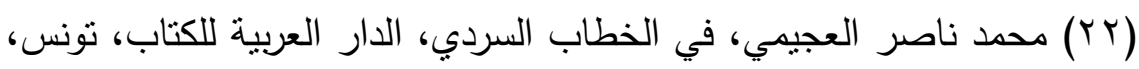
.1991

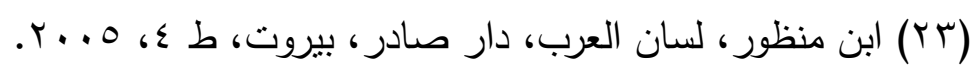

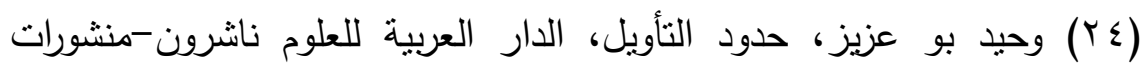

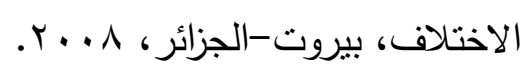




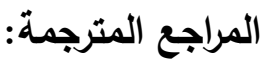

(1) آرت فان زويست التأويل والعلاماتية، من العلاماتية وعلم النص، ت منذر

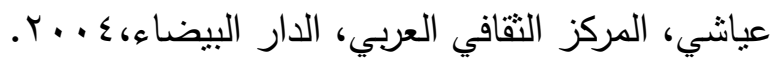

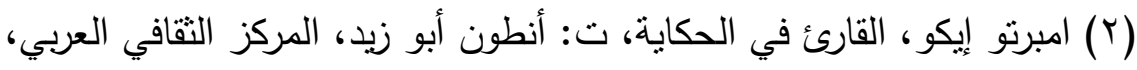

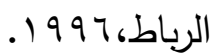

(r) امبرتو إيكو، حدود التأويل، ت: أنطون أبو زيد، المركز الثقافي العربي،

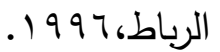

(ع) فريق انتروفرن، النحليل السيميائي للنصوص، ت حبيبة جرير، نينوى،

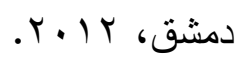

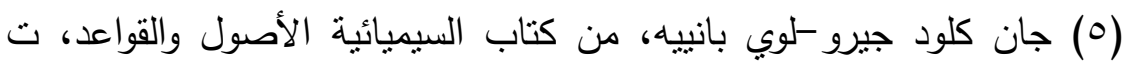

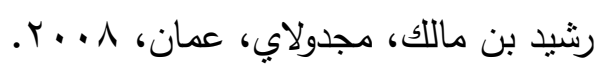

(7) جوليا كريشتيفا، علم النص، ت فريد الزاهي، توبقال، الدار البيضاء، ط؟،

$$
.199 \mathrm{~V}
$$

(V) جيرار جينت طروس من كتاب آفاق التناصية، ت محمد خير البقاعي،

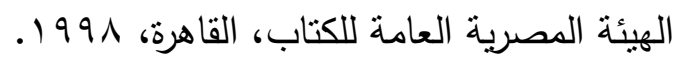

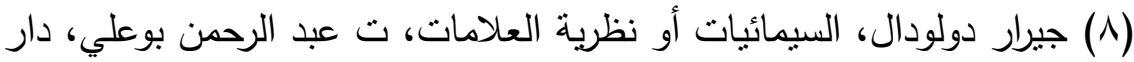

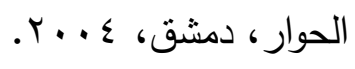

فانسان جوف، أثر الثخصية في الرواية، ت لحسن إحمامة، دار

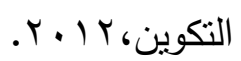

( • ( ) فليب هامون، من أجل نظام سيميائي للثخصية من كتاب شعرية المسرود،

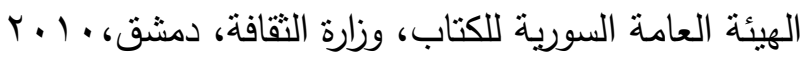

(1') هنري ميتزان من الفضاء الروائي، ت عبد الرحيم جزل، إفريقيا الثرق،

$$
\text { الدار البيضاء، r. r. r. }
$$

